\title{
Latent Liquidity: A New Measure of Liquidity, with an Application to Corporate Bonds *
}

\author{
Sriketan Mahanti ${ }^{1}$ Amrut Nashikkar ${ }^{2}$ Marti Subrahmanyam ${ }^{2, *}$ George Chacko $^{3}$ \\ Gaurav Mallik ${ }^{1}$
}

\begin{abstract}
We present a new measure of liquidity known as "latent liquidity" and apply it to a unique corporate bond database. Latent liquidity is defined as the weighted average turnover of investors who hold a bond, in which the weights are the fractional investor holdings. It can be used to measure liquidity in markets with sparse transactions data. For bonds that trade frequently, our measure has predictive power for both transaction costs and the price impact of trading, over and above trading activity and bond-specific characteristics thought to be related to liquidity. Additionally, this measure exhibits relationships with bond characteristics similar to those of other trade-based measures.
\end{abstract}

Key words: Fixed Income, Corporate Bonds, Liquidity, Asset Pricing, Market Microstructure JEL classification: G 100 (General Financial Markets)

\section{Introduction}

An investor holding a security or considering the purchase of a security is exposed to liquidity or, more precisely, the lack of it. In this paper, our goal is to understand the determinants of liquidity and its crosssectional variability in the context of relatively illiquid markets. While liquidity is easy to define in theoretical terms, its empirical measurement in an accurate and reliable manner is difficult, except for markets that are relatively very liquid. This is because most commonly used metrics of liquidity rely on transaction

\footnotetext{
* We are grateful to Peter Hecht and Jeffrey Sutthoff for their unstinting help and advice in putting together the databases for this paper. We thank Craig Emrick, Lasse Pedersen,and Caroline Shi for helpful suggestions on previous versions of the paper. We acknowledge, with thanks, comments from an anonymous referee and participants at the 2006 American Finance Association meetings in Boston, the CFA Research Institute Conference, the Journal of Investment Management Conference, the $Q$ Group Conference, and seminar participants at the Bank of Italy, Boston College, Harvard University, Santa Clara University, and the State Street Corporation Research Retreat. We record our appreciation for the detailed and insightful comments of an anonymous referee on previous drafts that led to a substantial revision of the paper. We thank State Street Corporation for providing us with some of the data used in this study and for financial support.

* Corresponding Author, Stern School of Business, 44, West Fourth Street \#9-68, New York, NY 10012 . Tel: +1 2129980348 Fax: +1 2129954233 .

Email address: msubrahm@stern.nyu.edu (Marti Subrahmanyam).

1 State Street Global Advisors, One Lincoln Street, Boston MA, 02111, USA

2 Stern School of Business, New York University, $44 \mathrm{~W}$ 4th Street, New York NY, 11220, USA

3 6S Capital GmbH, Bahnhofstrasse 11, 6300 Zug, Switzerland
} 
information, such as volume and trading spreads, with relatively high frequency, which are unavailable when the asset in question is illiquid.

In this paper, we propose a measure for liquidity that does not require such transactions data. Our measure is simply the weighted average turnover of investors who hold a particular bond, in which the weights are the fractional holdings of the amount outstanding of the bond. ${ }^{4}$ We call this measure latent liquidity, because it measures liquidity the way a typical sell-side dealer thinks about liquidity: it measures the accessibility of a security in terms of the sources that currently hold the security. We apply this measure to one of the most well-known, but illiquid markets in the world, the market for US corporate bonds. For bonds that trade relatively frequently, we show that our measure has predictive power both for transaction costs and for the price impact of trading, even after controlling for other liquidity measures such as the trading volume, and bond specific characteristics that are thought to be related to liquidity, such as age, amount outstanding, issuer size, rating class and coupon. Further, we analyze this new measure of liquidity further to try to understand the determinants of liquidity in the US corporate bond market.

Several theoretical justifications exist for our proposed measure of liquidity. The first is the inventory cost argument in the early microstructure literature of Garman (1976), Stoll (1978), and Amihud and Mendelson (1980), among others. This literature argues that the lower the trading frequency (or accessibility for any reason) for a particular security, the higher the need for a dealer to keep an inventory of the security and, therefore, the greater the transaction cost that the dealer needs to charge for providing the necessary inventory and search services. The second and related insight offered by Amihud and Mendelson (1986) is that, in equilibrium, securities with higher transaction costs and poorer liquidity are held by investors with longer trading horizons, because they are able to amortize their transaction costs over longer periods of time. The third is the insight from Vayanos and Wang (2005), who show that liquidity may get concentrated in some assets endogenously in equilibrium, leading to lower search times and lower transaction costs in these assets. The fourth is from the theoretical model of Duffie, Garleanu and Pedersen(2005), in which they endogenize transaction costs in a search-based framework for over-the-counter markets. They suggest that bid-ask spreads charged by market makers are likely to be higher when agents have lower trading frequencies and hence, fewer options to search. Taken together, these theoretical models suggest that bonds primarily held by agents with higher turnover should have better liquidity for two complimentary reasons. High turnover agents are attracted to securities with inherently lower trading costs, and the higher trading activity of these agents improves the liquidity of the assets they hold.

These theoretical ideas make intuitive sense in the context of the actual corporate bond market. Corporate bonds trade in a dealer network. Dealers rely on being able to access their buy-side clients' holdings either to purchase or sell bonds. If a bond is readily accessible, meaning a dealer can contact one of a number of buy-side clients and obtain the bond easily, the bond can be thought of as potentially liquid, even though it might not trade much. Specifically, we conjecture that if a bond issue is held primarily by investors with high portfolio turnover (e.g., hedge funds), the bond could be thought of as being more accessible, because it is easier for a dealer to contact one of the investors holding this bond, leading to lower search and transaction costs. Furthermore, high turnover funds have a greater incentive to hold such highly accessible bonds, because transaction costs are likely to be low when the bond has to be traded. Conversely, we conjecture that if a bond issue is held primarily by investors with low portfolio turnover, such as long term buy-and-hold investors (e.g., insurance companies), the bond is less accessible and, hence has higher search and transaction costs.

A common feature of empirical research in liquidity is that it generally uses transactions data, such as trading volume, trade count, or the bid-ask spread, to measure liquidity. This approach is feasible in markets that are reasonably liquid and have relatively continuous trading activity. However, the most interesting markets to study liquidity are those in which liquidity is a problem, such as the real estate market, or the corporate bond market, where transactions are few and far between, for all but a small subset of the assets. Conventional measures of liquidity such as the trading volume, trade count, and the bid-ask spread are difficult to employ in these markets, except for their most liquid segment. Even in these cases, the purchase

\footnotetext{
$\overline{4}$ We use the corporate bond market as an example of an illiquid market, but it should be clear that the liquidity concepts and measures discussed here apply, more generally, to any asset or security traded in an illiquid dealer market.
} 
and sale do not always occur at approximately the same time. Therefore, studies that use transactions data in these markets inevitably end up focusing on only the most liquid securities or markets. This is a classic case of looking for lost keys under the lamp post, where the light is shining, instead where they were lost. Clearly, what is needed is a measure of liquidity that does not rely on transactions data, particularly for illiquid markets. We propose such a measure in this paper.

Several authors have proposed measures of liquidity that do not rely on high-frequency data. Typically, these metrics rely only on daily volume and return data and can be related to the Kyle (1985) concept of the price impact of trading. Examples include the Amivest measure proposed by Amivest Capital Management, and the related Amihud (2002) measure, which are both based on absolute return and trading volume. The relationship between these measures (and their variants) and traditional microstructure-based measures is investigated by Hasbrouck (2005), who shows that the Amihud measure is a robust measure of price impact. However, in the absence of daily transactions data, even these measures are difficult to construct for most corporate bonds.

There is extensive literature on the transaction characteristics of corporate debt. ${ }^{5}$ Recently, attempts have been made to accurately quantify transaction costs in the market. Bessembinder, Maxwell and Venkataraman (2005) use National Association of Insurance Commissioners (NAIC) data to estimate round-trip transaction costs for a limited set of bonds using a signed-variable approach. Using the same dataset, Goldstein, Hotchkiss, and Sirri (2005) establish that transaction costs have decreased after the introduction of centralized reporting of transactions by the National Association of Securities Dealers (NASD) in 2002.

The impact of liquidity on the yield spread of corporate bonds over the riskless benchmarks has also been studied by several authors. ${ }^{6}$ However, transactions data in corporate bonds are sparse. ${ }^{7}$ Hence, in the absence of direct measures of liquidity for most corporate bonds, most researchers rely on indirect proxies such as age, amount outstanding, industry category, and credit risk. We provide a more refined measure of corporate bond liquidity in this paper. While these measures may be correlated with liquidity, it would be far better to obtain a more direct measure of liquidity, since these proxies for liquidity may be quite imperfect.

We use our measure of liquidity to analyze various characteristics of a bond, such as its credit rating and maturity, to determine whether or not each characteristic contributes to higher or lower liquidity, for that bond. Because the corporate bond market has a large number of dealers, obtaining data on this market is more difficult than for exchange-traded markets with a single locus of transactions. Few dealers has enough market share and, therefore, handle enough transactions for a meaningful analysis to be conducted. Even if they do, the transactions are likely to be less representative of the publicly traded market for US corporate bonds. For this reason, our dataset comes from one of the world's largest custody banks, which holds data from a large number of buy-side clients. As part of their custody process, these banks record the transactions conducted by their clients. Thus, the largest custody banks essentially see across the transactions databases of multiple dealers. While not being able to access data on all the transactions in the corporate bond market, the largest custodians do record a substantial proportion of it. More important, the custodians become aware of only institutional, not inter-dealer, trading. Thus, the database we use constitutes a more relevant portion of the trading universe (for the purpose of studying liquidity effects). As a result, the findings of the paper are much more appropriate for institutional trading and bond holdings.

\footnotetext{
5 Chakravarty and Sarkar (1999), Hong and Warga (2000), Schultz (2001), and Hotchkiss, Warga, and Jostava (2002) use the National Association of Insurance Commissioners (NAIC) database to study bid-ask spreads and trading volume in corporate bonds. Hotchkiss and Ronen (1999) and Alexander, Edwards, and Ferri (2000) use the Fixed Income Pricing System (FIPS) database of high-yield bonds, collected by the National Association of Securities Dealers (NASD) to study various aspects of corporate bond liquidity.

6 For instance, see Duffie and Singleton (1997) Elton, Gruber, Agrawal and Mann (2001), Collin-Dufresne, Goldstein and Martin (2001), Houweling, Mentink, and Vorst (2003), Huang and Huang (2003), Perraudin and Taylor (2003), Chen, Lesmond, and Wei (2005), Edwards, Harris and Piwowar (2006), Eom, Helwege and Huang (2004), Liu, Longstaff and Mandell (2004), Longstaff, Mithal and Neis (2005), and De Jong and Driessen (2005).

7 For example, Edwards, Harris and Piwowar (2006) show that of the 70,000+ corporate bonds outstanding in 2004, less than 17,000 experienced more than 9 trades that year.
} 
More recently, the NASD has introduced the Trade Reporting and Compliance Engine (TRACE) which provides a central repository of data on all transactions in TRACE eligible securities. However, TRACE data are available only from July 2002 onwards, and in the initial years, are not comprehensive. Even when all transactions are reported, they are still representative of only a small fraction of the universe of corporate bonds outstanding, namely traded securities and hence are inadequate for studying liquidity in the thinly traded section of the corporate bond market.

We first validate our measure in the set of traded bonds by estimating transaction costs in the corporate bond market using a sub-sample of bonds for which trading data are available in the TRACE database, using a limited dependent-variable model similar to Chen, Lesmond, and Wei (2005). We show that latent liquidity has explanatory power for cross-sectional transaction costs, over and above observable bond characteristics such as coupon, rating, age, issue size and issuer size, as well as realized trade count, on a quarterly basis. The inclusion of the latent liquidity variable eliminates the explanatory power of age and trade count for most quarters for which we are able to compute transactions costs. Unconditionally, there is a 200 basis point difference in transaction cost between the lowest ranked and the highest ranked bonds (by percentile of latent liquidity), and holding other variables constant, there is around a 91 basis point difference. As further validation of the hypothesis that latent liquidity conveys incremental information, we compute the price impact of trading corporate bonds using the TRACE database, using the Amihud (2002) measure. We find that latent liquidity explains price impact both unconditionally, and after controlling for issue size, issuer size, age, coupon, rating, and realized trade count. We find that, unconditionally, an increase in the latent liquidity percentile from $0 \%$ to $100 \%$ leads to a seven-fold decrease in the price impact, while, conditionally, it leads to around a two-fold decrease in the price impact. These results give us some comfort that the latent liquidity statistic is a good proxy for liquidity, with the advantage that it can be computed for bonds with little or no trading data.

We also investigate the drivers of bond liquidity, using latent liquidity as a proxy. We find that credit quality, age, issue size, the original maturity value at issue date, and optionality such as callability, putability, or convertibility all have a strong impact on our measure of liquidity. In these regressions, we use three different measures of liquidity as a dependent variable: our latent liquidity measure and the two transactionbased measures, which are alternative formulations of trading volume and, therefore, available only for the relatively liquid segment of our sample. We observe that, when we restrict ourselves to bonds in the liquid segment of our database that have a relatively high trading volume, the results from the regressions are similar, for most drivers of liquidity, whether we use latent liquidity or the transaction-based measures.

This paper is organized as follows. Section 2 introduces the database we use and provides some indication of how representative it is of the market as a whole, in terms of both holdings and transactions. It also provides some statistics on the trading frequency of bonds in our sample. This section also discusses the composition of the database in terms of various bond characteristics, such as issue size, age, maturity, industry segment, etc. Finally, the section concludes with a precise definition of latent liquidity, along with some graphs of the relationship between the proposed liquidity measure and key bond characteristics. Sections 3 and 4 compare the latent liquidity measure to two transaction-based liquidity measures calculated using corporate bond trades reported in the TRACE database. Section 3 defines a measure of transaction costs and Section 4 defines a measure of price impact. Latent liquidity has incremental explanatory power for both of these transaction-based measures, even after we control for bond characteristics and measures of trading activity. In Section 5, we investigate the relationship between latent liquidity and bond characteristics for both the liquid and the less liquid segment of our sample, to provide a sense of how different these are from the more liquid segment. We also relate the characteristics of bonds to two simple volume-based measures of liquidity, for the most liquid segment of the market, where the latter measures can be constructed. Section 6 concludes with a discussion of the implications of our proposed measure of liquidity for future research on corporate bonds. 


\section{Liquidity measurement and data}

While the corporate bond market appears to be an ideal market to study liquidity, two constraints have hampered empirical research in corporate bond liquidity so far. First, the corporate bond market is a dealer market. Until recently, no central data source existed for all the transactions occurring in the market. This has been remedied partially by the establishment of the TRACE effort in mid-2002. Second, even after the establishment of the TRACE database, in the absence of transactions data for all but the most liquid bonds, we need an alternative metric of liquidity, such as latent liquidity, that does not rely on such data.

\subsection{The US corporate bond database}

In our study, we use the databases of one of the world's largest custodial banks, State Street Corporation (SSC). The primary functions of a custodian are to provide trade clearance and settlement, the safekeeping of securities, and asset servicing such as dividend collection, proxy voting, and accounting and tax services. A custodian is not tied to any one dealer: its customers are the owners of assets, not the brokers or dealers. Asset owners typically use multiple dealers to execute their transactions but typically use one custodian for most, if not all of their holdings. Because a custodian is not associated with any single dealer, its data aggregates transactions across multiple dealers. Therefore, the transactions database of a custodian, particularly the largest one, should be much more comprehensive than that of any one individual dealer. Thus, the database is likely to be much more representative of the aggregate market, particularly relating to institutional investors. More important, unlike even the most comprehensive market database such as TRACE, a custodian's database contains information about both transaction prices and about the holdings and turnover of various investors, which we use for constructing our liquidity measure.

\subsection{A comparative analysis of the US corporate bond database}

The SSC holdings database represents a comparatively large sample of the publicly traded market for US corporate bonds, in terms of both holdings and transactions. It also covers a relatively long history from January 1994 to June $2006 .{ }^{8}$ We first present some evidence of the representative nature of the database in relation to the universe of US corporate bonds.

Table 1 presents the composition of our bond database broken down by industry, as compared with the total universe of US corporate bonds. The universe is defined based on data from Reuters, for the amount of bonds outstanding, in various industry segments as of June 30, 2006. As can be seen from the table, which presents the amounts outstanding in the various industry categories, our total sample represents about $14.52 \%$ of the whole market. ${ }^{9}$ We can see from this table that our database provides a good representation of the cross-section of bonds outstanding. The only significant deviation occurs in the banking and telephone industries. Banks are over-represented in our database (19.87\% vs $13.96 \%$ of the total universe). In contrast, our database is underweight in the telephone industry ( $4.98 \%$ vs $8.27 \%$ of the total universe).

Table 2 presents a similar disaggregation of our data in relation to the universe of US corporate bonds, based on Moody's credit rating. Our database's credit quality composition exhibits a somewhat greater deviation from the universe, as compared with the industry composition in Table 1. However, our database still remains reasonably representative of the universe, with our data being overrepresented in the high quality (Aaa and Aa) segment (12.20\% and $25.72 \%$, in the SSC sample, respectively, compared with $7.49 \%$ and $18.61 \%$ in the universe) and underrepresented in the low quality ( $\mathrm{C}$ and ungraded) segment $(0.21 \%$ and $7.32 \%$, respectively, compared with $0.66 \%$ and $9.53 \%$ in the universe). This is not surprising, considering that our holdings database consists of portfolios of institutional investors.

\footnotetext{
8 Unfortunately, some of the bond characteristics were not available in our database for the entire sample period. Consequently, we restrict our empirical analysis to the period from January 2000 to June 2005.

${ }^{9}$ We use the industry categories defined by Reuters.
} 
Table 1

Composition of bonds outstanding in the State Street Corporation custody database, by Industry: This table presents the composition, by Reuters industry category, of dollar-denominated US corporate bonds outstanding, as estimated by Reuters, as of June 30, 2006. This aggregate amount accounts for about $97 \%$ of the total US corporate bonds outstanding of $\$ 5,164.9$ billion, based on the data of the Bond Market Association (BMA) at http://www.bondmarkets.com/story.asp?id=2455. The first column defines the 11 industry categories, and the second and third columns show the amounts in billions of US dollars, of the total holdings in the markets for the universe of all issues, and for those issues for which State Street Corporation served as custodian. The fourth and fifth columns show the relative amounts in percent for the 11 industry categories in the Reuters and State Street databases, respectively. The last column indicates the relative amount held by State Street as a fraction of total US dollar amounts outstanding in each industry category.

\begin{tabular}{|c|c|c|c|c|c|}
\hline Industry & $\begin{array}{c}\text { Total } \\
\text { outstanding }\end{array}$ & $\begin{array}{l}\text { State Street } \\
\text { holdings }\end{array}$ & $\begin{array}{c}\text { Total } \\
\text { outstanding }\end{array}$ & $\begin{array}{l}\text { State Street } \\
\text { holdings }\end{array}$ & $\begin{array}{c}\text { State Street } \\
\text { holdings }\end{array}$ \\
\hline & $\begin{array}{l}\text { (billions of } \\
\text { US dollars) }\end{array}$ & $\begin{array}{l}\text { (billions of } \\
\text { US dollars) }\end{array}$ & $\begin{array}{c}\text { (as percent of } \\
\text { total) }\end{array}$ & $\begin{array}{c}\text { (as percent of } \\
\text { total) }\end{array}$ & $\begin{array}{c}\text { (as percent of } \\
\text { total outstanding) }\end{array}$ \\
\hline Banks & 701 & 145 & 13.96 & 19.87 & 20.67 \\
\hline Consumer Goods & 124 & 16 & 2.47 & 2.24 & 13.15 \\
\hline Electric Power & 284 & 34 & 5.65 & 4.73 & 12.16 \\
\hline Energy Company & 197 & 29 & 3.92 & 3.92 & 14.52 \\
\hline Gas Distribution & 22 & 2 & 0.43 & 0.34 & 11.25 \\
\hline Independent Finance & 35 & 3 & 0.69 & 0.45 & 9.38 \\
\hline Manufacturing & 563 & 72 & 11.21 & 9.87 & 12.78 \\
\hline Other Financial & 1,972 & 287 & 39.25 & 39.30 & 14.54 \\
\hline Service Company & 620 & 92 & 12.34 & 12.61 & 14.84 \\
\hline Telephone & 415 & 36 & 8.27 & 4.98 & 8.75 \\
\hline Transportation & 91 & 12 & 1.81 & 1.71 & 13.69 \\
\hline Total & 5,025 & 730 & 100 & 100 & 14.52 \\
\hline
\end{tabular}

Table 3 presents the disaggregated statistics for our database in relation to the universe, based on maturity. Again, our database remains reasonably representative of the universe, although it is somewhat underrepresented for the long maturity segment (greater than 10 years) - around $17.89 \%$ of the SSC sample compared with $24.69 \%$ in the universe and overrepresented for short maturities (less than 1 year) $-22.23 \%$ in the SSC sample as opposed to $12.32 \%$ in the entire universe.

We turn next to the transaction statistics for our database versus the whole market, based on data from the Bond Market Association (BMA). ${ }^{10}$ This is presented in Table 2. We cannot draw conclusions about the representativeness of the trades in our database for the various cross sections, because of the lack of comparable benchmarks for corporate bond transactions in the total universe. However, we do see that our sample is made up of over $6 \%$ of the average daily trading volume in US corporate bonds. This figure is on the conservative side because we restrict ourselves to the sample set of bonds for which clean security-level information and ratings data are available, which is a subset of our database. However, this is an indication that the database contains a slightly higher representation of illiquid issues relative to the broad corporate bond market. This level does not fluctuate much through time. The stability of trading volume gives some indication that the cross-sectional patterns, presented in Tables 1, 2 and 3, are fairly stable.

Based on the above comparisons, we can conclude that our database is reasonably representative of the publicly traded market for US corporate bonds. This conclusion holds in terms of the broad characteristics of the bond market, both for the cross-sectional holdings of the bonds and the way this cross section moves through time. We conjecture, therefore, that the conclusions we draw from this database should have relevance for the market as a whole.

\footnotetext{
$\overline{10}$ This database does not provide transactions statistics disaggregated into the various categories mentioned earlier. Furthermore, the statistics are available only on a monthly basis, and that too, only since January 2003.
} 
Table 2

Composition of bonds outstanding in the State Street Corporation custody database, by credit rating. This table presents the composition, by Moody's credit rating, of dollar-denominated US corporate bonds outstanding, as estimated by Reuters, as of May 31, 2006. This aggregate amount accounts for about $97 \%$ of the total US corporate bonds outstanding of $\$ 5,164.9$ billion, based on the data of the Bond Market Association (BMA) at http://www.bondmarkets.com/story.asp?id=2455. The first column defines the nine credit rating categories, and the second and third columns define the amounts in billions of US dollars, of the total holdings in the markets for the universe of all issues, and for those issues where State Street Corporation served as custodian. The third and fourth columns show the relative amounts in percent for the nine credit rating categories in the Reuters and State Street databases, respectively. The last column indicates the relative amount held by State Street, as a fraction of total US dollar amounts outstanding, in each credit rating category.

\begin{tabular}{|c|c|c|c|c|c|}
\hline $\begin{array}{l}\text { Credit } \\
\text { rating }\end{array}$ & $\begin{array}{l}\text { Total } \\
\text { outstandin }\end{array}$ & $\begin{array}{l}\text { State Street } \\
\text { holdings }\end{array}$ & $\begin{array}{l}\text { t Total } \\
\text { outstanding }\end{array}$ & $\begin{array}{l}\text { State Street } \\
\text { holdings }\end{array}$ & $\begin{array}{l}\text { State Street } \\
\text { holdings }\end{array}$ \\
\hline & (\$ billion) & ( $\$$ billion) & (as percent of total) & (as percent of total) & $\begin{array}{l}\text { (as percent of to- } \\
\text { tal) }\end{array}$ \\
\hline Aaa & 377 & 89 & 7.49 & 12.20 & 23.65 \\
\hline $\mathrm{Aa}$ & 935 & 188 & 18.61 & 25.72 & 20.07 \\
\hline A & 1,161 & 125 & 23.10 & 17.08 & 10.74 \\
\hline Baa & 905 & 119 & 18.01 & 16.32 & 13.16 \\
\hline $\mathrm{Ba}$ & 549 & 60 & 10.93 & 8.27 & 10.99 \\
\hline B & 379 & 73 & 7.54 & 9.97 & 19.20 \\
\hline $\mathrm{Caa}$ & 126 & 17 & 2.50 & 2.37 & 13.76 \\
\hline $\mathrm{Ca}$ & 81 & 4 & 1.62 & 0.53 & 4.77 \\
\hline $\mathrm{C}$ & 33 & 2 & 0.66 & 0.21 & 4.66 \\
\hline Other or NA Grade & 479 & 53 & 9.53 & 7.32 & 11.16 \\
\hline Total & 5,025 & 730 & 100 & 100 & 14.52 \\
\hline
\end{tabular}

\subsection{Characteristics of the US corporate bond database}

Our goal is to conduct a broad analysis of the liquidity in the US corporate bond market, based on the transactions in our database. Table 4 provides data on the liquidity of the corporate bond market based on the frequency of trading to support our claim that this market is highly illiquid. We see from this table that, across the years, few bonds trade every day in our sample. The number of bonds that trade approximately every day (defined as more than 200 days in a year) varies between zero and six; this is out of a sample of roughly nineteen thousand bonds. Even considering a level of trading of at least once a year as relatively liquid, the percentage of the total number of bonds in our sample that would be defined as liquid is between $22 \%$ and $34 \%$, each year. A large proportion of the bonds (over $40 \%$ ) do not even trade once a year. It should be noted that these statistics may overstate the liquidity problem in the market, since our database contains only a subset of all trades. These statistics throw some light on the problem of illiquidity in the corporate bond market and suggest that it would be futile to look for liquidity measures based only on trading data.

We now go into greater detail regarding the characteristics of the corporate bonds that are traded, based on our data set, over the period from January 2000 to December 2005. We give an indication in Table 6 about the trading characteristics of corporate bonds that trade in the marketplace. In general, we see that bond issues are split into one of 11 broad industry categories that we define (these are in line with the categories used by Reuters). The percentages in the various industry categories were fairly stable over the course of the 2000 - 2005 period. Bonds in the financial services industry (the banks and the other financial categories) traded the most during the sample period. This is not surprising because the financial services industry is the biggest issuer of corporate debt. In 2006, more than one-third of all new debt issues came from firms within this industry. Most financial services firms such as banks and insurance companies are highly leveraged entities, with substantial debt obligations. Table 7 shows how the trading characteristics of bonds by credit rating have been changing through time. During the early part of the sample period, a higher percentage 
Table 3

Composition of bonds outstanding in the State Street Corporation custody database, by maturity. This table presents the composition, by maturity, of dollar-denominated US corporate bonds outstanding, as estimated by Reuters, as of June 30, 2006. This aggregate amount accounts for about $97 \%$ of the total US corporate bonds outstanding of $\$ 5,164.9$ billion, based on the data of the Bond Market Association (BMA) at http://www.bondmarkets.com/story.asp?id=2455. The first column defines the thirteen maturity categories, and the second and third columns define the amounts, in billions of dollars of the total holdings in the markets, for the universe of all issues, and for those issues where State Street Corporation served as custodian. The third and fourth columns show the relative amounts in percent for the thirteen maturity categories in the Reuters and State Street databases, respectively. The last column indicates the relative amount held by State Street, as a fraction of total US dollar amounts outstanding, in each maturity category.

\begin{tabular}{|c|c|c|c|c|c|}
\hline $\begin{array}{l}\text { Time to } \\
\text { maturity }\end{array}$ & $\begin{array}{l}\text { Total } \\
\text { outstanding }\end{array}$ & $\begin{array}{l}\text { State Street } \\
\text { holdings }\end{array}$ & $\begin{array}{l}\text { Total } \\
\text { outstanding }\end{array}$ & $\begin{array}{l}\text { State Street } \\
\text { holdings }\end{array}$ & $\begin{array}{l}\text { State Street } \\
\text { holdings }\end{array}$ \\
\hline & & & \multicolumn{3}{|c|}{$\begin{array}{c}\text { as percent of total as percent of total as percent of to- } \\
\text { tal }\end{array}$} \\
\hline$<1$ year & 619 & 163 & 12.32 & 22.23 & 26.40 \\
\hline 2 years & 693 & 95 & 13.80 & 12.87 & 13.65 \\
\hline 3 years & 433 & 62 & 8.62 & 8.44 & 14.33 \\
\hline 4 years & 324 & 39 & 6.44 & 5.33 & 12.12 \\
\hline 5 years & 430 & 58 & 8.55 & 7.83 & 13.40 \\
\hline 6 years & 310 & 45 & 6.17 & 6.11 & 14.50 \\
\hline 7 years & 279 & 37 & 5.55 & 5.04 & 13.30 \\
\hline 8 years & 253 & 40 & 5.03 & 5.41 & 15.74 \\
\hline 9 years & 211 & 30 & 4.20 & 4.12 & 14.36 \\
\hline 10 years & 232 & 35 & 4.63 & 4.72 & 14.91 \\
\hline $11-15$ years & 361 & 23 & 7.18 & 3.13 & 6.38 \\
\hline 16 - 30 years & 790 & 101 & 15.72 & 13.78 & 12.82 \\
\hline$>30$ years & 90 & 7 & 1.79 & 0.98 & 8.03 \\
\hline Total & 5,025 & 735 & 100 & 100 & 14.63 \\
\hline
\end{tabular}

of investment grade bonds was traded. For example, in 2000, $76 \%$ of bond issues traded were rated as investment grade (with the rest being in the speculative category). Progressing through time, however, this proportion decreased to $66 \%$ in 2005 . Significant changes occurred in the marketplace, during the sample period. Equity markets dropped substantially during the early 2000s, indicating that the probability of default of most firms increased as well. This conclusion is supported by the fact that credit spreads also increased significantly during this time period. Therefore, if rating agencies were doing a reasonably good job, the conclusion that more bonds in the marketplace were getting rated below investment grade is natural.

We next present the trade data analyzed in terms of various bond characteristics such as maturity, time since issuance, face value and frequency of trading. We do this for each year, for data below each cumulative decile, during our sample period from 2000 to 2005. Table 8 displays the maturity structure of corporate debt traded in the marketplace. The average maturity of debt has not fluctuated much during the sample period. Table 9 shows that the time since issuance of traded debt has been fairly steady from 2000 until 2005. Table 10 shows the distribution of the outstanding face amount of all debt traded in the market. The table shows that the median face value amount of trades has increased substantially over the last five years. For the median bond, the face amount outstanding increased from $\$ 175$ million in 2000 to $\$ 250$ million in 2005. For the top decile, the corresponding numbers were $\$ 500$ million in 2000 going up to $\$ 800$ million in 2005; for the bottom decile, the face amount outstanding went up from $\$ 25$ million in 2000 to $\$ 100$ million in 2005 .

Table 11 provides us with a sense of the amount of trading activity that occurs in the US corporate bond market. Table 11, which is a variation of Table 5 , shows the average number of days that pass between trades 
Table 4

Comparision of trade volume between State Street Corporation custody compared to the whole market.This table presents statistics for the monthly traded volume (in billions of US dollars) of dollar-denominated US corporate bonds for the entire market versus the amount traded in the State Street Corporation custody holdings database during the period January 2000 to December 2005. Only securities greater than one year to maturity are considered. The aggregate market statistics are provided by the Bond Market Association at http://www.bondmarkets.com/story.asp?id=96. The first two columns indicate the date. The third and fourth columns indicate the average daily par quantity traded in the State Street database, and in the market respectively. The last column indicates the ratio of the amount traded from State Street holdings to that for the entire market (expressed as a percentage).

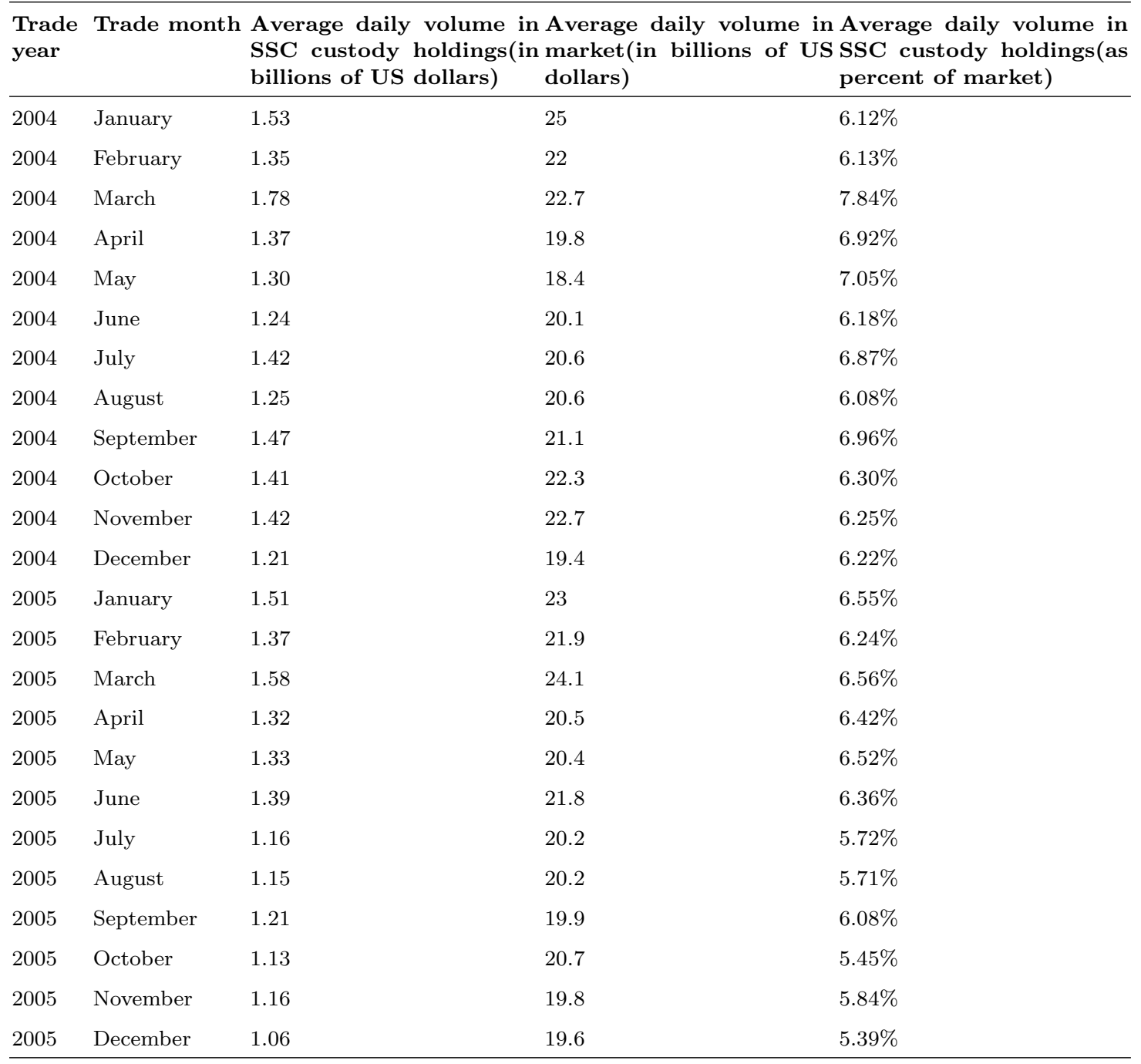

for a bond issue, for those bonds that are traded. As shown in Table 3, most bonds did not have any trades for many years. We exclude them from the analysis presented in Table 11. For the median traded bond, the average time between trades varied between 12 days and 18 days within the sample period. (There are roughly twenty - two trading days in a calendar month.) For the median stock, in comparison, this value is more on the order of minutes. For the most liquid stocks, this statistic is in seconds. Therefore, we see from Tables 10 and 11 that the corporate bond market is orders of magnitude more illiquid than the stock market, even if we were to consider the liquid segment of the corporate bond market (as represented by the traded set). 
Table 5

Trade distribution by the frequency of trading. This table presents statistics for the distribution of issues by frequency of trade, of US corporate dollar denominated bonds in the State Street Corporation custody trades database during the period from January 2000 to December 2005. The frequency of trading of an issue is defined as the number of distinct trading days in a given year. The data show the number of issues corresponding to a particular trading frequency in each year. For example, in 2003, five issues traded more than 200 days and 42 issues traded between 150 and 200 days.

\begin{tabular}{llllllll}
\hline Frequency of trading & \multicolumn{2}{l}{$\mathbf{2 0 0 0}$} & $\mathbf{2 0 0 1}$ & $\mathbf{2 0 0 2}$ & $\mathbf{2 0 0 3}$ & $\mathbf{2 0 0 4}$ & $\mathbf{2 0 0 5}$ \\
\hline$>200$ days in year & 0 & 2 & 5 & 5 & 3 & 6 \\
150-200 days in year & 11 & 16 & 33 & 42 & 25 & 14 \\
100-150 days in year & 38 & 80 & 152 & 146 & 149 & 116 \\
$50-100$ days in year & 273 & 401 & 621 & 786 & 730 & 739 \\
30-50 days in year & 502 & 675 & 774 & 940 & 1007 & 961 \\
10-30 days in year & 1862 & 2169 & 2377 & 2439 & 2722 & 2672 \\
$5-10$ days in year & 1544 & 1716 & 1568 & 1754 & 1742 & 1580 \\
At least 1 day and atmost 5 days in year 6191 & 5866 & 4987 & 5006 & 4786 & 4335 \\
No trade in year & 7872 & 6979 & 7163 & 8262 & 8397 & 8693 \\
& & & & & & \\
\hline Total issues & 18293 & 17904 & 17680 & 19380 & 19561 & 19116 \\
\hline
\end{tabular}

Table 6

Trade distribution by industry sector. This table presents the distribution of trade market value, by industry sector, as defined by Reuters, of dollar-denominated US corporate bonds in the State Street Corporation custody trades database during the period from January 2000 to December 2005. The trading distribution of a given industry sector is expressed as a percentage of total market value of trades, for the given year, within the State Street custody database.

\begin{tabular}{|c|c|c|c|c|c|c|}
\hline Industry Sector & 2000 & 2001 & 2002 & 2003 & 2004 & 2005 \\
\hline$(\%)$ & $(\%)$ & $(\%)$ & $(\%)$ & $(\%)$ & $(\%)$ & $(\%)$ \\
\hline Banks & 10.0 & 9.0 & 9.0 & 8.0 & 10.0 & 9.0 \\
\hline Telephone & 13.0 & 12.0 & 9.0 & 7.0 & 7.0 & 7.0 \\
\hline Manufacturing & 15.0 & 14.0 & 14.0 & 17.0 & 15.0 & 15.0 \\
\hline Consumer Goods & 3.0 & 3.0 & 4.0 & 4.0 & 3.0 & 2.0 \\
\hline Electric Power & 4.0 & 6.0 & 5.0 & 7.0 & 6.0 & 6.0 \\
\hline Energy Company & 6.0 & 5.0 & 6.0 & 5.0 & 5.0 & 5.0 \\
\hline Transportation & 2.0 & 2.0 & 2.0 & 1.0 & 2.0 & 1.0 \\
\hline Other Financial & 33.0 & 32.0 & 33.0 & 32.0 & 34.0 & 36.0 \\
\hline Service Company & 15.0 & 16.0 & 17.0 & 19.0 & 17.0 & 18.0 \\
\hline Gas Distribution & 0.0 & 0.0 & 0.0 & 0.0 & 0.0 & 0.0 \\
\hline Independent Finance & 0.0 & 0.0 & 1.0 & 1.0 & 1.0 & 1.0 \\
\hline
\end{tabular}

\subsection{Liquidity measurement}

The previous subsection provided strong evidence in support of the conclusion that the US corporate bond market is extremely illiquid. Therefore, in many ways, this market seems a much more relevant setting to study the problems of illiquidity and its consequences. However, one important problem remains. Most corporate bonds rarely trade. This makes it difficult to distinguish between whether a given bond is more liquid than another, particularly if both bonds do not trade for several days or even months. For example, if one bond trades six times a year and a second one trades three times a year, the amount of trading in both cases is too small to conclude that the first bond is twice as liquid as the second.

Our proposed measure gives a better sense of the relative liquidity of the two bonds. In a dealer, or over- 
Table 7

Trading distribution by credit rating. This table presents the distribution of trade market value, by credit rating, as defined by Moodys, of dollar-denominated US corporate bonds, in the State Street Corporation custody trades database during the period from January 2000 to December 2005. The trading distribution of a given credit rating is expressed as percentage of total market value of trades for the given year within the State Streets custody trades database.

Credit Rating 200020012002200320042005

\begin{tabular}{lcccccc}
$(\%)$ & $(\%)$ & $(\%)$ & $(\%)$ & $(\%)$ & $(\%)$ & $(\%)$ \\
\hline Aaa & 2.0 & 3.0 & 4.0 & 4.0 & 4.0 & 3.0 \\
Aa & 12.0 & 12.0 & 12.0 & 11.0 & 13.0 & 14.0 \\
A & 38.0 & 38.0 & 30.0 & 24.0 & 25.0 & 21.0 \\
Baa & 23.0 & 28.0 & 30.0 & 29.0 & 26.0 & 29.0 \\
Below Baa & 24.0 & 20.0 & 24.0 & 33.0 & 31.0 & 34.0 \\
\hline
\end{tabular}

Table 8

Percentile distribution of trades, by maturity (in years). This table presents the distribution of maturity, in years, of trades in dollar-denominated US corporate bonds, in the State Street Corporation custody trades database during the period from January 2000 to December 2005. The maturity of a bond is defined as the years remaining to maturity. Bonds that trade in a given year are sorted in the order of increasing maturity, and the decile cutoff values are computed. The value shown is the maturity of the bond at the given percentile. For example, the data show that the median trade had a time to maturity of 5.6 years in 2000 and 5.9 years in 2005.

\begin{tabular}{|c|c|c|c|c|c|c|}
\hline & 00 & ח0 & 20 & & & \\
\hline 10 & 1.0 & 0.9 & 0.9 & 1.0 & 1.1 & 1.0 \\
\hline 20 & 1.9 & 1.9 & 2.0 & 2.2 & 2.2 & 2.0 \\
\hline 30 & 3.0 & 3.0 & 3.2 & 3.4 & 3.4 & 3.1 \\
\hline 40 & 4.3 & 4.4 & 4.5 & 4.6 & 4.6 & 4.5 \\
\hline 50 & 5.6 & 5.6 & 5.5 & 5.6 & 5.9 & 5.9 \\
\hline 60 & 7.0 & 6.8 & 6.8 & 7.2 & 7.4 & 7.2 \\
\hline 70 & 8.3 & 8.2 & 8.7 & 9.2 & 9.1 & 8.8 \\
\hline 80 & 9.9 & 10.0 & 10.6 & 12.1 & 11.4 & 11.0 \\
\hline 90 & 22.7 & 22.4 & 22.9 & 23.2 & 22.2 & 21.6 \\
\hline
\end{tabular}

Table 9

Percentile distribution of trades, by age (in years). This table presents the distribution of age, in years, of trades in dollardenominated US denominated bonds, in the State Street Corporation custody trades database during the period from January 2000 to December 2005. The age of a bond is defined as the number of years since its issue. Bonds that trade in a given year are sorted in the order of increasing age, and the decile cutoff values are computed. The value shown is the age of the bond at the given percentile. For example, the data show that the median trade had an age of 2.5 years in 2000 and 2.3 years in 2005 .

\begin{tabular}{|c|c|c|c|c|c|c|}
\hline & & 0 & & & & \\
\hline 10 & 0.2 & 0.1 & 0.2 & 0.1 & 0.1 & 0.1 \\
\hline 20 & 0.7 & 0.6 & 0.7 & 0.4 & 0.4 & 0.6 \\
\hline 30 & 1.4 & 1.4 & 1.4 & 1.0 & 0.9 & 1.1 \\
\hline 40 & 2.0 & 2.2 & 2.3 & 1.8 & 1.5 & 1.7 \\
\hline 50 & 2.5 & 3.0 & 3.3 & 2.8 & 2.4 & 2.3 \\
\hline 60 & 3.1 & 3.7 & 4.2 & 4.2 & 3.5 & 3.3 \\
\hline 70 & 4.0 & 4.5 & 5.0 & 5.2 & 5.1 & 4.6 \\
\hline 80 & 5.3 & 5.9 & 6.4 & 6.4 & 6.5 & 6.8 \\
\hline 90 & 7.5 & 8.2 & 8.9 & 8.4 & 8.4 & 8.7 \\
\hline
\end{tabular}


Table 10

Percentile distribution of trades, by face value outstanding (millions of US dollars): This table presents the distribution of face value (in millions of US Dollars) of trades in corporate dollar-denominated bonds, in the State Street Corporation custody trades database, during the period from January 2000 to December 2005. The face value of a bond is defined as the amount outstanding on the trade date. Bonds that trade in a given year, are sorted in the order of increasing face amount and the decile cutoff values are computed. The value shown is the average face value of the bond for the given percentile. For example, the data shows that the median trade had a face value of 175 million dollars in 2000 and 250 million dollars in 2005.

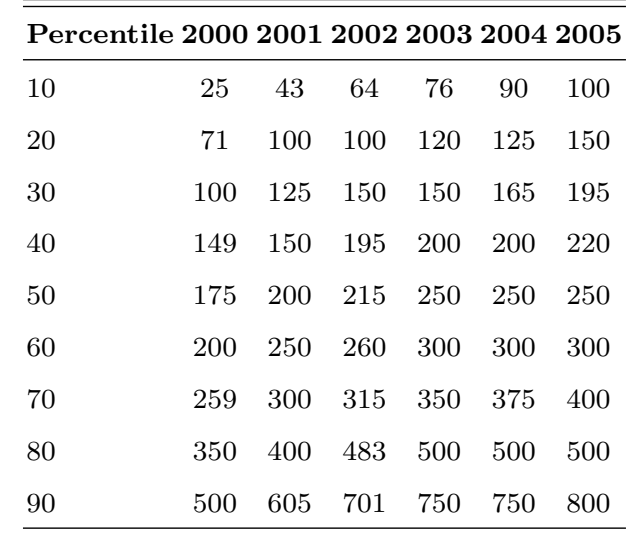

Table 11

Percentile distribution of trades, by time elapsed between successive trades (in days). This table presents the distribution of time elapsed between trades (in days) of trades in dollar-denominated US corporate bonds in the State Street Corporation custody trades database during the period from January 2000 to December 2005. The time elapsed is defined as the number of days between successive trades of a given bond. Bonds that trade in a given year are sorted in the order of increasing time elapsed and the decile cutoff values are computed. The values shown are the average time elapsed of the bond for the given percentile range. For example, the data shows that the median trade had an elapsed time of 14 days in 2000 between successive trades and 12 days in 2005 .

\begin{tabular}{|c|c|c|c|c|c|c|}
\hline \multicolumn{3}{|c|}{ Percentile 20002001} & \multicolumn{4}{|c|}{2002200320042005} \\
\hline 10 & 1 & 1 & 1 & 1 & 1 & 1 \\
\hline 20 & 3 & 3 & 3 & 2 & 2 & 2 \\
\hline 30 & 6 & 7 & 6 & 4 & 4 & 4 \\
\hline 40 & 9 & 13 & 10 & 7 & 8 & 8 \\
\hline 50 & 14 & 22 & 18 & 13 & 13 & 12 \\
\hline 60 & 21 & 35 & 31 & 24 & 23 & 21 \\
\hline 70 & 30 & 56 & 54 & 42 & 40 & 39 \\
\hline 80 & 44 & 93 & 100 & 82 & 79 & 78 \\
\hline 90 & 77 & 171 & 206 & 184 & 187 & 188 \\
\hline
\end{tabular}

the-counter (OTC), market what really determines the liquidity of a security is the ease with which a dealer can access a security. For example, if a buy order comes in to a dealer, she could supply that order out of her own inventory, or she could try to source the bonds from the inventory of one of her other customers. In other words, the dealer could "work the order" by contacting customers to see if she can convince someone to sell her the bonds to fill the buy order. ${ }^{11}$ Consider the case in which she is trying to call customers to fill the buy order. If the bond issue of interest is held primarily by funds with high turnover (hedge funds, for example), it should be easier for the dealer to contact one of them and to convince them to sell her the needed bonds, than if the bonds were held primarily by funds with low turnover (insurance companies, for

\footnotetext{
${ }^{11}$ The dealer will, of course, try to buy the bonds at a lower price from the customer than the price at which she will fill the buy order. Thus, she earns a fee for her "search services."
} 
example). ${ }^{12}$ This is because the high turnover funds are used to trading in and out of securities with high frequency, at least, relative to many fixed income investors, who tend to buy and hold bonds till maturity. Thus, they could be more easily convinced to trade a particular security they are holding. Therefore, whether a bond issue experiences a great deal of trading volume or not, we can say that a bond issue is more liquid in our sense, if it is more accessible by dealers. We define such access in terms of the turnover of the investors holding the bond issue. In the context of the accessibility of a security, the search costs and times are likely to be lower for bonds that are held primarily by high turnover agents.

This measure of accessibility of a security is not a direct measure of liquidity, but rather a latent measure. To measure latent liquidity, we need to be able to determine, for each bond issue, which of the many types of investors hold the issue, and the aggregate weighted average turnover of all the investors holding the issue. If the weighted average turnover of all the funds holding a particular bond issue is high, then we say that the bond issue has high latent liquidity. In other words, it is more accessible, relative to another bond that has lower latent liquidity. Latent liquidity, in that sense, can be thought of as the degree to which it is held by investors who are expected to trade more frequently, based on historical trading patterns. Once again, a custodian is in an ideal position to obtain the information needed to calculate latent liquidity. Custodians are aware of not only trading information, but also the individual portfolio holdings. Therefore, if we look at the historical custodial holdings database, we can calculate a 12-month historical turnover number for all portfolios. For any particular bond issue, we aggregate across all the investors holding that issue, to calculate a weighted average turnover measure. This statistic becomes our latent liquidity measure for that particular bond.

More formally, we define the fractional holding of bond $i$ (as a percentage of the total outstanding amount of the bond issue in our database) by fund $j$ at the end of month $t$ as $\pi_{j, t}^{i}$. Also, we define the average portfolio turnover of fund $j$ from month $t$ to month $t-12$ as $T_{j, t}$, where the portfolio turnover is defined as the ratio of the dollar trading volume of fund $j$ from month $t$ to month $t-12$ to the value of fund $j$ at the end of month $t$. Latent liquidity for bond $i$ in month $t$ is defined as

$$
L_{t}^{i}=\sum_{j} \pi_{j, t}^{i} T_{j, t}
$$

Therefore, we define latent liquidity for any bond $i$, at any time $t$, as the aggregate weighted-average level of turnover of the individual funds holding bond $i$.

The most convenient feature of this measure is that it is based entirely on investors' aggregate holdings and does not require data on individual transactions. Therefore, this measure can be calculated even in the absence of trading in a particular bond. Furthermore, this measure can be calculated accurately, on a monthly basis, for every public bond issue, given the unique nature of our database, which consists of data on both transactions and holdings of a large set of investors in the market.

Figs. 1 through 5 present the patterns of changes in latent liquidity with respect to changes in certain bond characteristics, that are often used as proxies for liquidity. To generate these figures, we rank bonds into percentiles (scaled 0-1 in our empirical work and presented in the graphs and tables), based on their latent liquidity, where 0 represents the lowest liquidity level and 1 the highest liquidity level. For each bond characteristic, the latent liquidity percentile rank is averaged across bonds with a particular value of the characteristic. The graphs represent the relationship between the (average) latent liquidity and the particular bond characteristic.

\footnotetext{
$\overline{12}$ Of course, one can define a whole continuum of customers, in terms of their propensity to trade, rather than the two referred to in the example.
} 


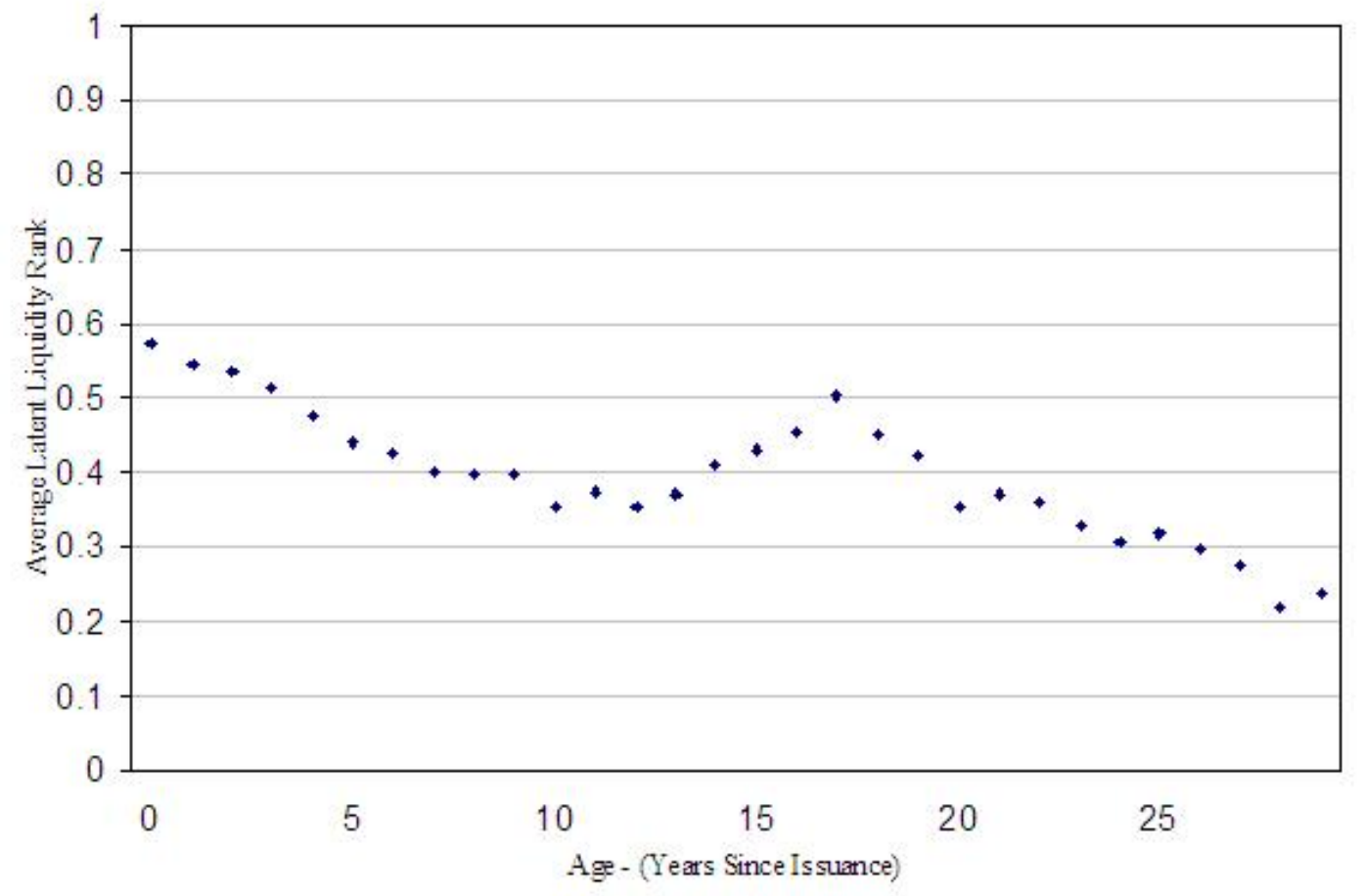

Fig. 1. Latent liquidity rating as a function of bond age. This figure presents the pattern of changes in the average latent liquidity with respect to age of bond (in years) for trades in US corporate dollar-denominated bonds in the State Street Corporation custody trades database during the period from January 2000 to December 2005. The latent liquidity of a bond is defined as the aggregate weighted-average level of turnover of the investors holding the bond. The age of a bond is defined as the number of years since issue. The values of the latent liquidity rank vary between 0 and 1 , where 0 represents the lowest liquidity level and 1 the highest liquidity level.

Fig. 1 plots the (average) latent liquidity of bonds in relation to their age, from the time they were first issued until maturity. We observe that bonds are at their peak latent liquidity levels when they are just issued. Their latent liquidity level decreases steadily after issuance until final maturity. This is consistent with, but more specific than, the casual evidence that on-the-run bonds are more liquid than their off-the-run counterparts. The conjecture that emerges is that many bonds are initially placed into high turnover funds, who then flip the bonds to lower turnover (usually buy-and-hold) funds. We see that latent liquidity values are greater than 0.5 , on average, for bonds with an age of less than one year and, in general, decrease over time to a value of less than 0.3 for bonds with an age greater than 26 years.

Fig. 2 shows the relationship between (average) latent liquidity and issue size. Generally speaking, there is a positive correlation between issue size and liquidity. The biggest improvement in liquidity occurs for issue sizes below $\$ 600$ million. The latent liquidity is relatively flat, thereafter, although there are significant deviations from this pattern, on either side. This initial improvement could possibly have to do with the minimum issue size requirements for the inclusion of bonds in popular bond indices such as the Lehman Aggregate Index. ${ }^{13}$

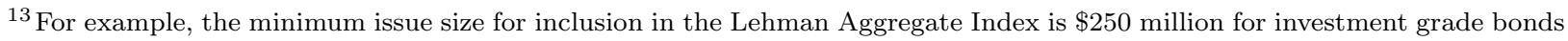
and $\$ 100$ million for high-yield bonds.
} 


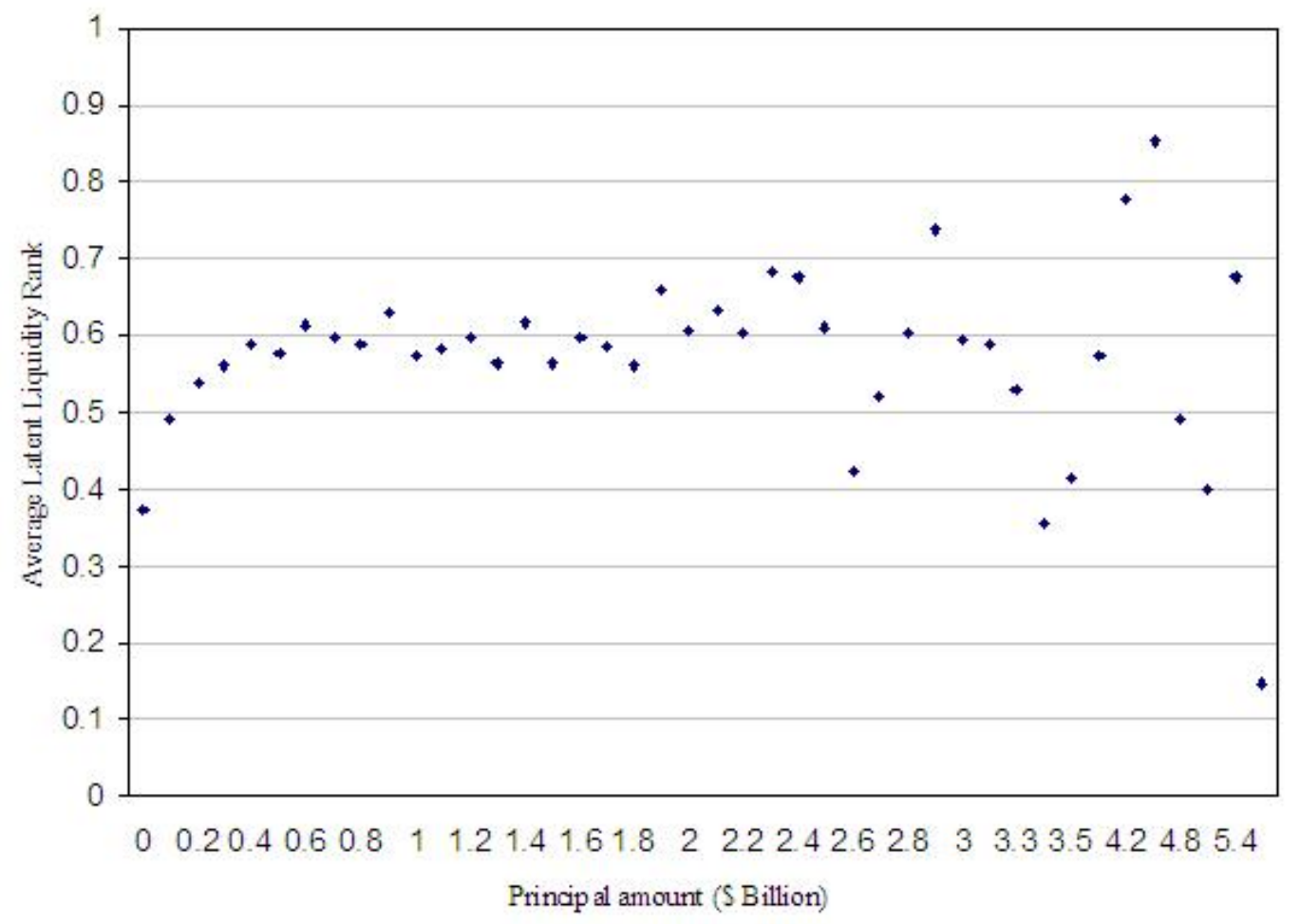

Fig. 2. Latent liquidity rating as a function of issue size: This figure presents the pattern of changes in the average latent liquidity with respect to issue size (in billions of US dollars) for trades in US corporate dollar-denominated bonds in the State Street Corporation custody trades database during the period from January 2000 to December 2005. The latent liquidity of a bond is defined as the aggregate weighted-average level of turnover of the investors holding the bond. The values of the latent liquidity rank vary between 0 and 1, where 0 represents the lowest liquidity level and 1 the highest liquidity level. Issue size is defined as the amount of principal at issuance.

Fig. 3 provides a plot of the (average) latent liquidity versus time to maturity for bond issues. We observe that the longer the maturity of a bond, the higher its latent liquidity, although there are clear jumps in the pattern at certain maturity levels. The jumps in this figure are initially surprising but easily explained: They are the result of bond issues of standard maturities. For instance, bonds with a ten-year maturity are of two types: bonds that were issued in the past and are now down to ten years to maturity, i.e. off-the-run bonds and bonds that have just been issued, i.e. on-the-run bonds. However, bonds with a 11-year maturity are likely to be mostly off-the-run bonds (because 11 years is seldom chosen as a maturity time for newly issued bonds). Therefore, the significantly higher latent liquidity of the on-the-run bonds at the ten-year maturity level results in a substantially higher latent liquidity measure at the ten-year level versus the 11-year level; hence, the observed jump in the graph. ${ }^{14}$ The same result holds at typical maturity points for new issues, such as at 20 and 30 years.

Fig. 4 presents the (average) latent liquidity as a function of coupon rates over the sample period. There is no clear pattern in this relationship, because coupon effects are confounded by credit rating, age, maturity, and issue date, given that there are strong correlations between the coupon rate and these bond characteristics. In a loose sense, it appears that issues with a higher coupon rate enjoy greater liquidity than those with

\footnotetext{
${ }^{14}$ This could motivate some hedge funds to act as liquidity providers by buying the off-the-run bonds and going short on-the-run bonds.
} 


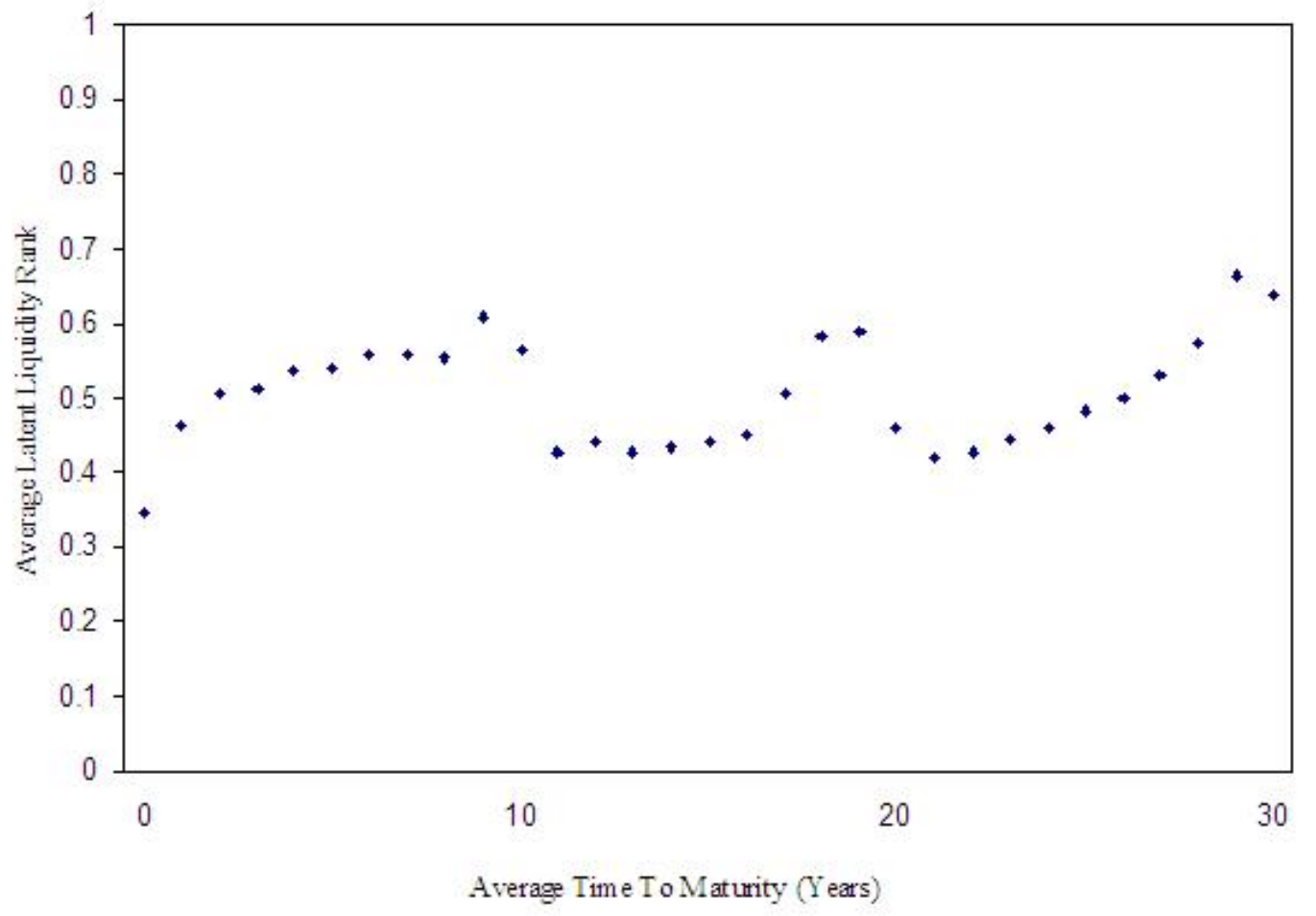

Fig. 3. Latent liquidity as a function of maturity: This figure presents the pattern of changes in the average latent liquidity with respect to time to maturity (in years) for trades in US corporate dollar-denominated bonds in the State Street Corporation custody trades database during the period from January 2000 to December 2005. The latent liquidity of a bond is defined as the aggregate weighted-average level of turnover of the investors holding the bond. The age of a bond is defined as the number of years since the issue date. The values of the latent liquidity rating vary between 0 and 1 , where 0 represents the lowest liquidity level and 1 the highest liquidity level.

a lower coupon. However, it appears that zero coupon bonds are more liquid than bonds with a promised coupon rate of up to approximately $10 \%$. This could result from the desirability of zero coupon issues for implementing hedging and cash matching strategies.

Fig. 5 represents the (average) latent liquidity as a function of Moody's credit rating. We observe that latent liquidity steadily improves as we move down in credit quality. We explore this issue further in Section 5.

\section{Latent liquidity and transaction costs}

Before investigating the drivers of latent liquidity, we show an application of the concept of latent liquidity in the prediction of transaction costs in the bond market and in doing so, present a validation of our measure. The recent literature on transaction costs contains several different approaches for estimating transaction costs. Bessembinder, Maxwell, and Venkataraman (2005) use data reported by insurance companies to the National Association of Insurance Companies to estimate round-trip transaction costs for a limited set of bonds using a signed-variable approach. Using the same dataset, Goldstein, Hotchkiss and Sirri (2005) establish that transaction costs have decreased after the introduction of reporting on TRACE. However, both these methodologies require the use of signed trades and are limited in scope to the trades reported by insurance companies. Unfortunately, TRACE data, as made available by the NASD, does not have buy 


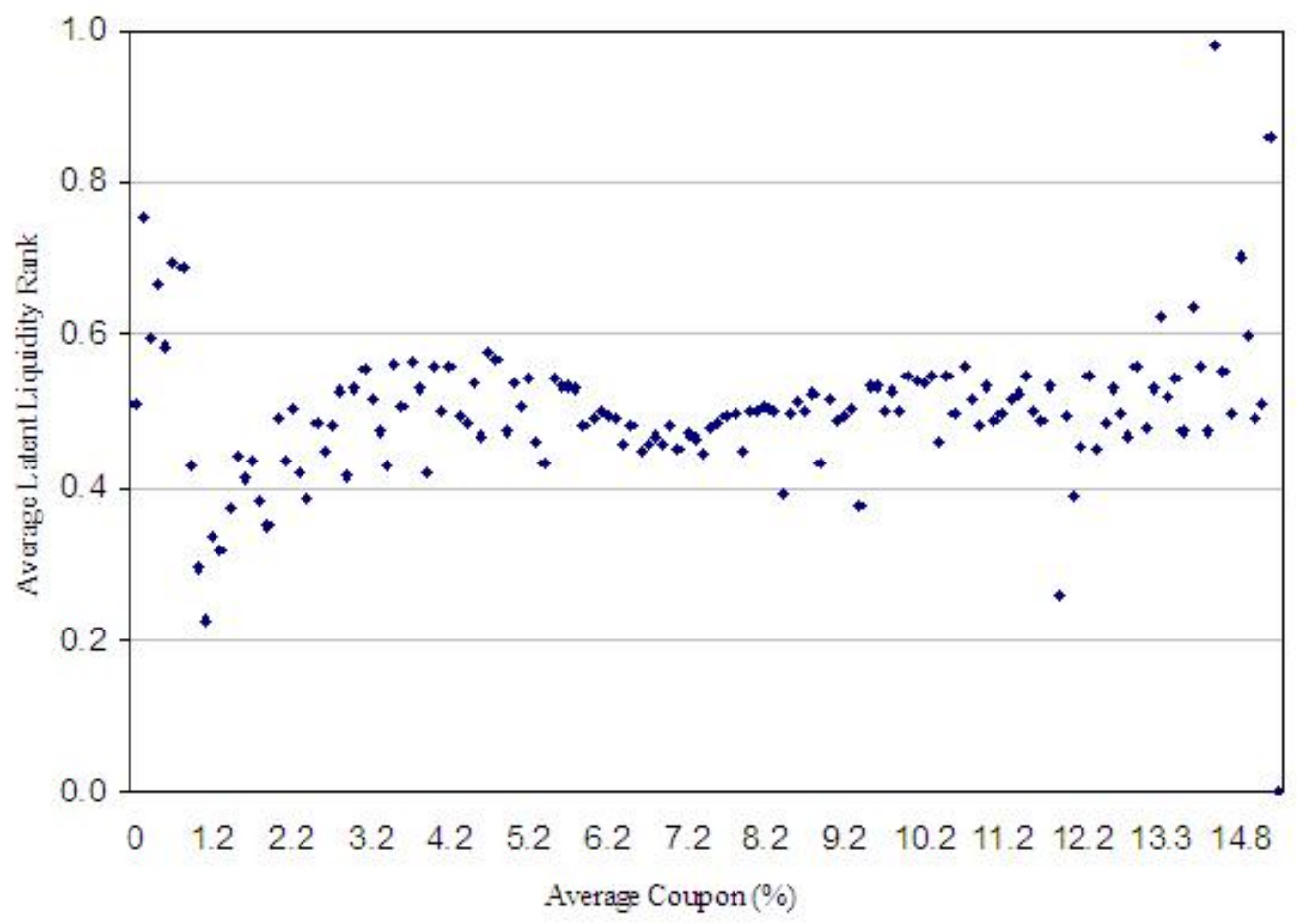

Fig. 4. Latent liquidity as a function of coupon: This figure presents the pattern of changes in the average latent liquidity with respect to coupon (in percent) for trades in US corporate dollar-denominated bonds in the State Street Corporation custody trades database during the period from January 2000 to December 2005. The latent liquidity of a bond is defined as the aggregate weighted-average level of turnover of the investors holding the bond. The coupon is defined as the annual payment in relation to the principal amount of the bond. The values of the latent liquidity rank vary between 0 and 1 , where 0 represents the lowest liquidity level and 1 the highest liquidity level.

or sell identifiers for trades, although it covers a much broader segment of the market, both in terms of the cross section of instruments traded and the number of market participants. Hence, for the purpose of estimating transaction costs in bonds, we use the limited dependent variable approach of Chen, Lesmond, and Wei (2006). This method allows us to form estimates of transaction costs only on the basis of only the last traded prices for every day in the TRACE database. A detailed explanation of the method is given in the appendix. The estimated transaction costs are in percentages, normalized by the price of the bond. Our estimates of transaction costs are comparable in magnitude to those obtained by Chen, Lesmond, and Wei (2006), both across rating and maturity classes. The only point of departure from their method is in our use of transactions reported on TRACE for the computation of return series in bonds, as opposed to their approach of using Datastream daily prices, which represents quotes from a much smaller set of contributors. We also attempted an alternate specification using changes in interest rates and the changes in the credit default swap (CDS) premium, obtained from a leading broker in the CDS market, for the issuer of a bond as a measure of its "true" return. However, the CDS market itself is liquid for only a fraction of all the bonds traded in the market and often has fewer observed returns than the bond itself. Thus, such an analysis severely restricts the number of bonds for which we can estimate transaction costs. It is possible to pursue this issue further as the liquidity of the CDS market improves.

Univariate regressions of the transaction cost estimates on latent liquidity for each quarter are presented 


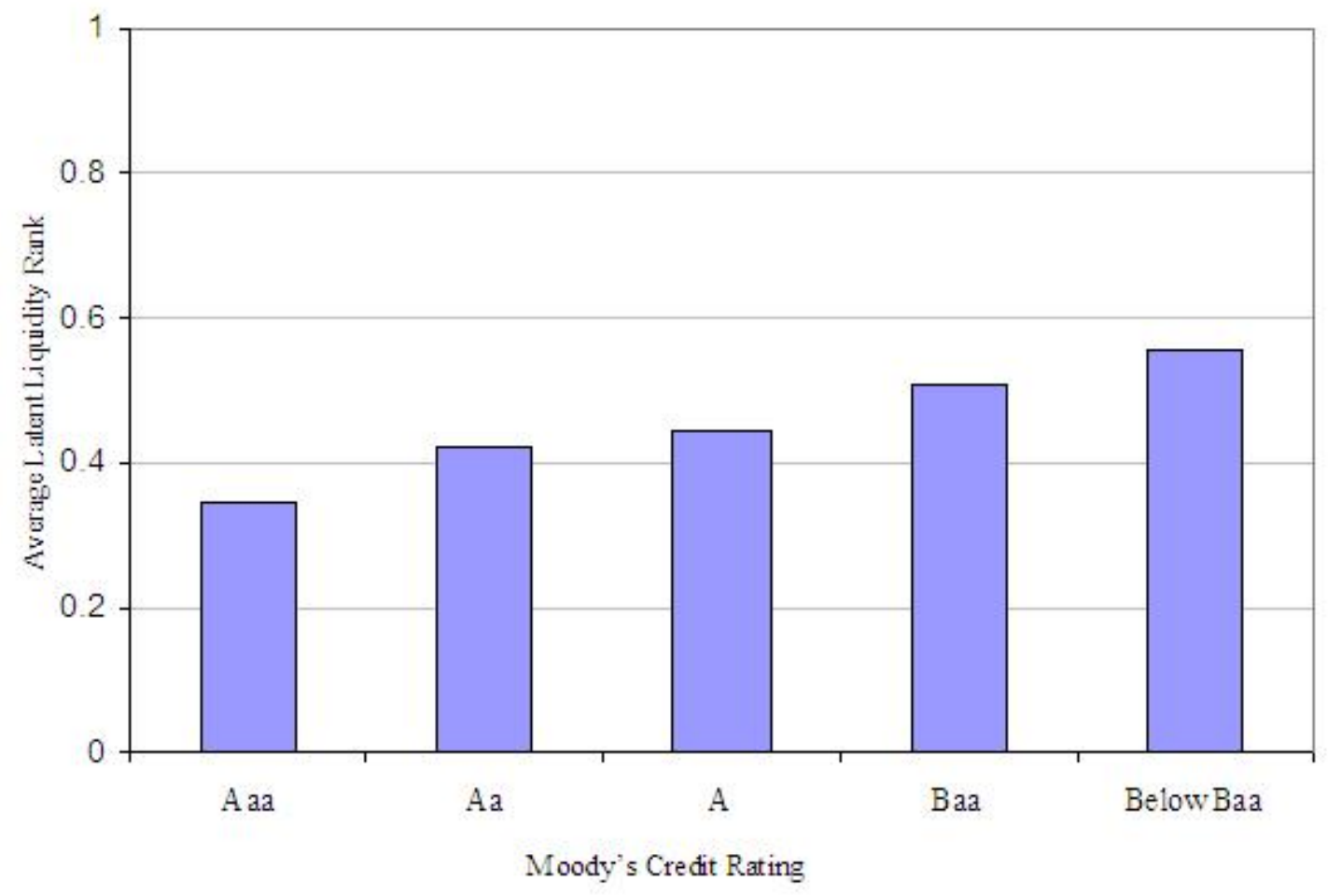

Fig. 5. Latent liquidity as a function of Moody's ratings categories: This figure gives the average value of latent liquidity for various Moodys credit rating categories in US corporate dollar-denominated bonds in the State Street Corporation custody trades database during the period from January 2000 to December 2005. The latent liquidity of a bond is defined as the aggregate weighted-average level of turnover of the investors holding the bond. The values of the latent liquidity rank vary between 0 and 1 , where 0 represents the lowest liquidity level and 1 the highest liquidity level.

in Table 12. Here, we use the percentile rank of latent liquidity of the bond. Each bond is ranked on a scale of 0 to 1 (from less liquid to more liquid) within a quarter. Thus, we interpret our measures to be ordinal and not cardinal measures of liquidity. This avoids the effect of large outliers in the data and has the additional advantage of making the measure comparable from one quarter to another regardless of changes in overall trading volumes in the market or changes in coverage of bonds by SSC.

The coefficient of the latent liquidity variable is consistently negative for all quarters. In an overall sense, going from a percentile rank of 0 to $100 \%$ (0-1 in our scale) leads to a reduction in estimated transaction costs of around 200 basis points. However, if latent liquidity is a better measure of liquidity than realized measures such as trade count or trade volume, we would expect latent liquidity at the beginning of a quarter to have explanatory power even after controlling for the realized trading count during the quarter, and bondspecific variables that primarily drive liquidity such as issuer size, outstanding amount, coupon, rating and age. We test this relation on quarterly estimates of transaction costs in our bonds for the period from July 2002 (when substantial reporting on TRACE begins) to June 2006. These results are reported in Table 13. The estimation of transaction costs requires us to have bonds with a minimum of five trade observations in any given quarter. This requirement, along with the fact that we are considering an intersection of trades reported on TRACE with the SSC database, and for which firm size can be determined from Compustat, restricts the number of bonds in our sample for every quarter to the numbers that are reported in Table 13. It is clear that, with the passage of time, trading activity as reported on the TRACE database has increased, as evidenced by the increasing number of bonds available in our sample.

Even after controlling for other variables, the coefficient of the latent liquidity percentile is negative for 14 out of the 16 quarters in our sample period, and is significant for nine out of the 16 quarters in our data-set. 
Table 12

Univariate regressions of transaction costs and price impacts on latent liquidity. This table shows, quarter by quarter, univariate regressions of the transaction costs estimates and of Amihud's ILLIQ measure of price impact calculated using TRACE data for a given quarter for a bond and its percentile rank (from 0 to 1 ) on the basis of latent liquidity. The transaction costs are estimated using a limited dependent variable model for every bond for every quarter using the 5 year interest rate and the return on the S\&P index as benchmarks. The percentile rank of latent liquidity is computed by ranking bonds every quarter in terms of latent liquidity and then dividing the bonds by the number of bonds available for that quarter. The first rank is given to the lowest liquidity security. This gives a measure that is comparable from quarter to quarter. The sample consists of bonds that are traded on TRACE for a minimum of five days every quarter, and for whom information on latent liquidity is available from the State Street Corporation holdings database. The time period covered is July 2002 to June 2006. Robust t statistics are in parentheses. $*$ significant at $5 \%$ level; ** significant at $1 \%$ level

\begin{tabular}{|c|c|c|c|c|c|c|}
\hline & Transaction & ts (percen & of price) & & (ILLIQ) & \\
\hline Quarter & Latent Liquid & Constant & -squared & tent liquid & Constant & -squarec \\
\hline Q302 & -0.439 & 0.469 & 0.01 & -1.998 & -10.988 & 0.02 \\
\hline & $(1.22)$ & $(1.74)$ & & $(2.11)^{*}$ & $(15.72)^{* *}$ & \\
\hline Q402 & -0.953 & 0.858 & 0.02 & 1.136 & -13.018 & 0.01 \\
\hline & $(2.24)^{*}$ & $(2.65)^{* *}$ & & $(1.44)$ & $(21.69)^{* *}$ & \\
\hline Q103 & -0.608 & 0.946 & 0.01 & -4.087 & -8.916 & 0.13 \\
\hline & $(2.60)^{* *}$ & $(6.37)^{* *}$ & & $(9.44)^{* *}$ & $(32.86)^{* *}$ & \\
\hline Q203 & -1.422 & 1.686 & 0.03 & -3.599 & -9.207 & 0.12 \\
\hline & $(4.24)^{* *}$ & $(8.09)^{* *}$ & & $(9.60)^{* *}$ & $(39.57)^{* *}$ & \\
\hline Q303 & -2.059 & 2.103 & 0.05 & -3.394 & -9.271 & 0.11 \\
\hline & $(5.95)^{* *}$ & $(10.14)^{* *}$ & & $(9.29)^{* *}$ & $(42.52)^{* *}$ & \\
\hline Q403 & -2.217 & 2.209 & 0.05 & -2.979 & -9.448 & 0.09 \\
\hline & $(6.15)^{* *}$ & $(10.43)^{* *}$ & & $(8.73)^{* *}$ & $(47.21)^{* *}$ & \\
\hline Q104 & -2.303 & 2.065 & 0.05 & -3.745 & -9.499 & 0.09 \\
\hline & $(6.48)^{* *}$ & $(10.31)^{* *}$ & & $(8.88)^{* *}$ & $(39.91)^{* *}$ & \\
\hline Q204 & -2.617 & 2.367 & 0.05 & -4.209 & -9.136 & 0.11 \\
\hline & $(6.73)^{* *}$ & $(10.57)^{* *}$ & & $(10.22)^{* *}$ & $(38.71)^{* *}$ & \\
\hline Q304 & -2.530 & 2.452 & 0.04 & -3.114 & -9.901 & 0.06 \\
\hline & $(6.17)^{* *}$ & $(10.18)^{* *}$ & & $(7.46)^{* *}$ & $(40.14)^{* *}$ & \\
\hline Q404 & -2.801 & 2.971 & 0.06 & -1.994 & -10.131 & 0.03 \\
\hline & $(9.84)^{* *}$ & $(16.82)^{* *}$ & & $(7.56)^{* *}$ & $(62.39)^{* *}$ & \\
\hline Q105 & -2.232 & 2.934 & 0.03 & -1.129 & -10.667 & 0.01 \\
\hline & $(7.11)^{* *}$ & $(14.74)^{* *}$ & & $(4.23)^{* *}$ & $(63.05)^{* *}$ & \\
\hline Q205 & -2.235 & 2.906 & 0.03 & -1.350 & -10.237 & 0.02 \\
\hline & $(6.19)^{* *}$ & $(12.53)^{* *}$ & & $(5.41)^{* *}$ & $(63.90)^{* *}$ & \\
\hline Q305 & -2.284 & 2.950 & 0.03 & -1.581 & -10.196 & 0.03 \\
\hline & $(6.53)^{* *}$ & $(13.03)^{* *}$ & & $(6.12)^{* *}$ & $(60.94)^{* *}$ & \\
\hline Q405 & -1.898 & 2.680 & 0.02 & -1.224 & -10.290 & 0.01 \\
\hline & $(5.19)^{* *}$ & $(11.38)^{* *}$ & & $(4.40)^{* *}$ & $(57.53)^{* *}$ & \\
\hline Q106 & -3.016 & 3.284 & 0.04 & -1.514 & -10.265 & 0.02 \\
\hline & $(7.08)^{* *}$ & $(11.62)^{* *}$ & & $(4.77)^{* *}$ & $(48.69)^{* *}$ & \\
\hline Q206 & -2.240 & 2.916 & 0.02 & -1.694 & -9.998 & 0.03 \\
\hline & $(5.40)^{* *}$ & $(10.49)^{* *}$ & & $(5.49)^{* *}$ & $(48.32)^{* *}$ & \\
\hline Overall & -2.024 & 2.460 & 0.03 & -2.171 & -9.977 & 0.04 \\
\hline & $(21.24)^{* *}$ & $(40.91)^{* *}$ & & $(25.82)^{* *}$ & $(188.51)^{* *}$ & \\
\hline
\end{tabular}


Table 13

Transaction costs, liquidity and bond characteristics. This table shows, quarter by quarter, the relationship between the transaction costs as a percentage of price estimated from TRACE data for a given quarter for a bond and two liquidity-related variables- the bond's percentile rank (from 0 to 1 ) based on latent liquidity for that quarter and the average number of trades in the bond during that quarter, along with five other bond characteristics - coupon, rating class (as a number from 1-7), Maturity (in years), amount outstanding of the bond in the market, and the size of the issuer as measured by total assets at the beginning of the year. The transaction costs are estimated using a limited dependent variable model for every bond for every quarter using the 5 year interest rate and the return on the S\&P index as benchmarks. The percentile rank is computed by ranking bonds every quarter in terms of latent liquidity and then dividing the bonds by the number of bonds available for that quarter. The first rank is given to the lowest liquidity security. The sample consists of bonds that are traded on TRACE for a minimum of five days every quarter, and for whom information on latent liquidity is available from the State Street Corporation custody holdings database. The time period covered is July 2002 to June 2006. Robust t statistics are in parentheses. ${ }^{*}$ significant at $5 \%$ level; $* *$ significant at $1 \%$ level

\begin{tabular}{|c|c|c|c|c|c|c|c|c|c|c|c|}
\hline & Latent Liquidity & Coupon & Maturity & Log(Amount OS $)$ & $\log$ (Assets) & Age & Rating & Tradecount & Cons & Obs & $R^{2}$ \\
\hline Q302 & $\begin{array}{l}0.389 \\
(0.97)\end{array}$ & $\begin{array}{r}-0.026 \\
(0.73)\end{array}$ & $\begin{array}{l}0.008 \\
(1.15)\end{array}$ & $\begin{array}{c}-0.144 \\
(1.01)\end{array}$ & $\begin{array}{l}-0.010 \\
(0.20)\end{array}$ & $\begin{array}{l}0.043 \\
(1.16)\end{array}$ & $\begin{array}{l}-0.102 \\
(1.29)\end{array}$ & $\begin{array}{r}-0.000 \\
(0.20)\end{array}$ & $\begin{array}{l}3.328 \\
(1.14)\end{array}$ & 165 & 0.04 \\
\hline Q402 & $\begin{array}{l}0.136 \\
(0.36)\end{array}$ & $\begin{array}{c}-0.009 \\
(0.26)\end{array}$ & $\begin{array}{l}0.006 \\
(1.00)\end{array}$ & $\begin{array}{l}-0.047 \\
(0.35)\end{array}$ & $\begin{array}{l}0.001 \\
(0.02)\end{array}$ & $\begin{array}{l}0.016 \\
(0.49)\end{array}$ & $\begin{array}{l}-0.072 \\
(1.01)\end{array}$ & $\begin{array}{r}-0.000 \\
(0.51)\end{array}$ & $\begin{array}{l}1.187 \\
(0.43)\end{array}$ & 165 & 0.03 \\
\hline Q103 & $\begin{array}{l}-0.115 \\
(0.44)\end{array}$ & $\begin{array}{l}-0.076 \\
(2.00)^{*}\end{array}$ & $\begin{array}{c}0.014 \\
(2.71)^{* *}\end{array}$ & $\begin{array}{c}-0.356 \\
(4.86)^{* *}\end{array}$ & $\begin{array}{l}0.033 \\
(0.90)\end{array}$ & $\begin{array}{l}0.006 \\
(0.27)\end{array}$ & $\begin{array}{l}0.016 \\
(0.22)\end{array}$ & $\begin{array}{l}0.000 \\
(0.32)\end{array}$ & $\begin{array}{c}7.690 \\
(5.27)^{* *}\end{array}$ & 480 & 0.10 \\
\hline Q203 & $\begin{array}{l}-0.046 \\
(0.13)\end{array}$ & $\begin{array}{l}0.006 \\
(0.11)\end{array}$ & $\begin{array}{c}0.022 \\
(3.80)^{* *}\end{array}$ & $\begin{array}{c}-0.755 \\
(6.51)^{* *}\end{array}$ & $\begin{array}{c}-0.193 \\
(3.59)^{* *}\end{array}$ & $\begin{array}{l}-0.036 \\
(1.25)\end{array}$ & $\begin{array}{l}-0.195 \\
(1.84)\end{array}$ & $\begin{array}{l}-0.001 \\
(1.67)\end{array}$ & $\begin{array}{c}18.593 \\
(8.08)^{* *}\end{array}$ & 586 & 0.23 \\
\hline Q303 & $\begin{array}{c}-0.044 \\
(0.11)\end{array}$ & $\begin{array}{l}0.022 \\
(0.40)\end{array}$ & $\begin{array}{c}0.032 \\
(4.92)^{* *}\end{array}$ & $\begin{array}{c}-0.694 \\
(6.05)^{* *}\end{array}$ & $\begin{array}{c}-0.313 \\
(5.72)^{* *}\end{array}$ & $\begin{array}{c}0.059 \\
(2.00)^{*}\end{array}$ & $\begin{array}{l}-0.267 \\
(2.45)^{*}\end{array}$ & $\begin{array}{r}-0.000 \\
(0.18)\end{array}$ & $\begin{array}{c}18.431 \\
(8.21)^{* *}\end{array}$ & 621 & 0.25 \\
\hline Q403 & $\begin{array}{r}-0.272 \\
(0.71)\end{array}$ & $\begin{array}{l}0.022 \\
(0.43)\end{array}$ & $\begin{array}{c}0.043 \\
(6.70)^{* *}\end{array}$ & $\begin{array}{c}-0.856 \\
(8.30)^{* *}\end{array}$ & $\begin{array}{c}-0.163 \\
(3.03)^{* *}\end{array}$ & $\begin{array}{c}0.069 \\
(2.45)^{*}\end{array}$ & $\begin{array}{l}-0.213 \\
(2.08)^{*}\end{array}$ & $\begin{array}{r}-0.000 \\
(0.04)\end{array}$ & $\begin{array}{c}19.921 \\
(9.66)^{* *}\end{array}$ & 667 & 0.30 \\
\hline Q104 & $\begin{array}{l}-0.508 \\
(1.34)\end{array}$ & $\begin{array}{c}0.134 \\
(2.64)^{* *}\end{array}$ & $\begin{array}{c}0.036 \\
(5.73)^{* *}\end{array}$ & $\begin{array}{c}-0.711 \\
(6.85)^{* *}\end{array}$ & $\begin{array}{c}-0.187 \\
(3.71)^{* *}\end{array}$ & $\begin{array}{l}-0.047 \\
(1.66)\end{array}$ & $\begin{array}{c}-0.310 \\
(3.22)^{* *}\end{array}$ & $\begin{array}{r}-0.000 \\
(0.51)\end{array}$ & $\begin{array}{c}17.382 \\
(8.53)^{* *}\end{array}$ & 656 & 0.23 \\
\hline Q204 & $\begin{array}{c}-1.339 \\
(3.12)^{* *}\end{array}$ & $\begin{array}{l}0.042 \\
(0.78)\end{array}$ & $\begin{array}{c}0.038 \\
(5.22)^{* *}\end{array}$ & $\begin{array}{c}-0.480 \\
(4.37)^{* *}\end{array}$ & $\begin{array}{l}-0.102 \\
(1.82)\end{array}$ & $\begin{array}{l}0.002 \\
(0.08)\end{array}$ & $\begin{array}{l}-0.050 \\
(0.47)\end{array}$ & $\begin{array}{l}-0.001 \\
(2.14)^{*}\end{array}$ & $\begin{array}{c}12.061 \\
(5.63)^{* *}\end{array}$ & 697 & 0.18 \\
\hline Q304 & $\begin{array}{r}-0.890 \\
(1.89)\end{array}$ & $\begin{array}{l}0.107 \\
(1.72)\end{array}$ & $\begin{array}{c}0.030 \\
(3.49)^{* *}\end{array}$ & $\begin{array}{c}-0.486 \\
(4.05)^{* *}\end{array}$ & $\begin{array}{c}-0.202 \\
(3.36)^{* *}\end{array}$ & $\begin{array}{r}-0.031 \\
(0.93)\end{array}$ & $\begin{array}{c}-0.306 \\
(2.65)^{* *}\end{array}$ & $\begin{array}{c}-0.002 \\
(2.76)^{* *}\end{array}$ & $\begin{array}{c}13.855 \\
(5.87)^{* *}\end{array}$ & 724 & 0.15 \\
\hline Q404 & $\begin{array}{c}-1.083 \\
(3.60)^{* *}\end{array}$ & $\begin{array}{l}0.066 \\
(1.64)\end{array}$ & $\begin{array}{c}0.032 \\
(5.93)^{* *}\end{array}$ & $\begin{array}{c}-0.766 \\
(9.24)^{* *}\end{array}$ & $\begin{array}{c}-0.201 \\
(4.25)^{* *}\end{array}$ & $\begin{array}{l}0.011 \\
(0.58)\end{array}$ & $\begin{array}{c}-0.251 \\
(3.26)^{* *}\end{array}$ & $\begin{array}{c}-0.002 \\
(5.48)^{* *}\end{array}$ & $\begin{array}{c}19.643 \\
(11.78)^{* *}\end{array}$ & 1323 & 0.23 \\
\hline Q105 & $\begin{array}{c}-1.333 \\
(3.96)^{* *}\end{array}$ & $\begin{array}{c}0.162 \\
(3.37)^{* *}\end{array}$ & $\begin{array}{c}0.014 \\
(2.29)^{*}\end{array}$ & $\begin{array}{c}-1.027 \\
(10.37)^{* *}\end{array}$ & $\begin{array}{l}-0.075 \\
(1.42)\end{array}$ & $\begin{array}{c}-0.054 \\
(2.41)^{*}\end{array}$ & $\begin{array}{c}-0.358 \\
(4.02)^{* *}\end{array}$ & $\begin{array}{c}-0.001 \\
(4.10)^{* *}\end{array}$ & $\begin{array}{c}23.906 \\
(12.01)^{* *}\end{array}$ & 1352 & 0.15 \\
\hline Q205 & $\begin{array}{c}-1.427 \\
(3.69)^{* *}\end{array}$ & $\begin{array}{l}0.075 \\
(1.42)\end{array}$ & $\begin{array}{c}0.028 \\
(3.99)^{* *}\end{array}$ & $\begin{array}{c}-1.086 \\
(9.64)^{* *}\end{array}$ & $\begin{array}{l}-0.103 \\
(1.76)\end{array}$ & $\begin{array}{r}-0.012 \\
(0.56)\end{array}$ & $\begin{array}{r}-0.180 \\
(1.82)\end{array}$ & $\begin{array}{c}-0.002 \\
(4.15)^{* *}\end{array}$ & $\begin{array}{c}25.073 \\
(11.11)^{* *}\end{array}$ & 1216 & 0.16 \\
\hline Q305 & $\begin{array}{c}-1.202 \\
(3.45)^{* *}\end{array}$ & $\begin{array}{c}0.142 \\
(3.22)^{* *}\end{array}$ & $\begin{array}{c}0.025 \\
(4.07)^{* *}\end{array}$ & $\begin{array}{c}-0.850 \\
(8.62)^{* *}\end{array}$ & $\begin{array}{l}-0.076 \\
(1.52)\end{array}$ & $\begin{array}{l}-0.013 \\
(0.75)\end{array}$ & $\begin{array}{l}-0.211 \\
(2.45)^{*}\end{array}$ & $\begin{array}{c}-0.008 \\
(9.45)^{* *}\end{array}$ & $\begin{array}{c}20.049 \\
(10.15)^{* *}\end{array}$ & 1183 & 0.26 \\
\hline Q405 & $\begin{array}{c}-1.544 \\
(4.31)^{* *}\end{array}$ & $\begin{array}{c}0.090 \\
(2.02)^{*}\end{array}$ & $\begin{array}{c}0.033 \\
(5.64)^{* *}\end{array}$ & $\begin{array}{c}-0.895 \\
(8.82)^{* *}\end{array}$ & $\begin{array}{l}-0.093 \\
(1.86)\end{array}$ & $\begin{array}{l}-0.008 \\
(0.41)\end{array}$ & $\begin{array}{l}0.030 \\
(0.34)\end{array}$ & $\begin{array}{c}-0.008 \\
(8.85)^{* *}\end{array}$ & $\begin{array}{c}20.685 \\
(10.35)^{* *}\end{array}$ & 1142 & 0.30 \\
\hline Q106 & $\begin{array}{c}-2.181 \\
(4.70)^{* *}\end{array}$ & $\begin{array}{l}0.108 \\
(1.85)\end{array}$ & $\begin{array}{c}0.035 \\
(4.54)^{* *}\end{array}$ & $\begin{array}{c}-1.008 \\
(7.96)^{* *}\end{array}$ & $\begin{array}{l}-0.009 \\
(0.15)\end{array}$ & $\begin{array}{l}0.020 \\
(0.79)\end{array}$ & $\begin{array}{l}0.052 \\
(0.46)\end{array}$ & $\begin{array}{c}-0.003 \\
(4.28)^{* *}\end{array}$ & $\begin{array}{c}21.728 \\
(8.61)^{* *}\end{array}$ & 934 & 0.22 \\
\hline Q206 & $\begin{array}{c}-1.621 \\
(3.95)^{* *}\end{array}$ & $\begin{array}{l}0.074 \\
(1.48)\end{array}$ & $\begin{array}{c}0.035 \\
(5.54)^{* *}\end{array}$ & $\begin{array}{c}-0.791 \\
(8.71)^{* *}\end{array}$ & $\begin{array}{l}-0.133 \\
(2.41)^{*}\end{array}$ & $\begin{array}{l}0.020 \\
(0.93)\end{array}$ & $\begin{array}{l}-0.082 \\
(0.90)\end{array}$ & $\begin{array}{c}-0.005 \\
(7.28)^{* *}\end{array}$ & $\begin{array}{c}19.288 \\
(10.33)^{* *}\end{array}$ & 1003 & 0.26 \\
\hline Overall & $\begin{array}{c}-0.918 \\
(9.05)^{* *}\end{array}$ & $\begin{array}{c}0.061 \\
(4.58)^{* *}\end{array}$ & $\begin{array}{c}0.030 \\
(16.49)^{* *}\end{array}$ & $\begin{array}{c}-0.865 \\
(31.89)^{* *}\end{array}$ & $\begin{array}{c}-0.127 \\
(8.62)^{* *}\end{array}$ & $\begin{array}{l}0.011 \\
(1.74)\end{array}$ & $\begin{array}{c}-0.080 \\
(3.23)^{* *}\end{array}$ & $\begin{array}{c}-0.001 \\
(6.58)^{* *}\end{array}$ & $\begin{array}{c}20.011 \\
(36.95)^{* *}\end{array}$ & 12914 & 0.19 \\
\hline
\end{tabular}

The lack of statistical significance in the earlier quarters of our sample is possibly because of a lower number of observations reported in the TRACE database. Overall, after controlling for realized liquidity in the form of trade count and bond characteristics that primarily drive liquidity in bonds, we still find that there is a 91 basis point difference in transaction costs between the most liquid and the least liquid bonds in our sample. It is apparent that latent liquidity has explanatory power even after controlling for common measures of realized liquidity, as well as bond-specific variables.

This result is important because it shows that not only do bond characteristics and the realized liquidity of a bond drive its transaction costs, but also its accessibility, as measured by latent liquidity. It is also significant in these regressions that latent liquidity has a true predictive relationship, because we use beginning of the 
quarter latent liquidity to predict transaction costs within the quarter, even after accounting for the trade count during the quarter. Furthermore, the consistency of the coefficients across quarters gives us confidence that our results are robust across time. These results give us confidence that latent liquidity is a meaningful and viable measure of liquidity that can be applied to both traded and non traded bonds.

\section{Latent liquidity and price impact}

Another way through which illiquidity manifests itself is in the price impact of trading a security. Several trade-based measures of price impact have been shown in the literature, of which the measure proposed by Amihud (2002), based on the $\lambda$ measure of Kyle (1985), is the most intuitive and simple to implement. We use the Amihud measure of price impact (henceforth called ILLIQ), which is simply the average ratio of the absolute return in a bond to its trading volume in any given period. If the absolute return during a day t is $\left|r_{t}\right|$ and the trading volume on that day is $V_{t}$, the average Amihud measure over a period of $\mathrm{T}$ days is given by

$$
I L L I Q_{T}=\frac{1}{T} \sum_{t=1}^{T} \frac{\left|r_{t}\right|}{V_{t}} .
$$

A higher value of the measure implies a greater price impact of trading and, consequently, lower liquidity. Price impact is also positively correlated with transaction costs. ${ }^{15}$ It is useful to assess the predictive power of the other liquidity variables in assessing price impact as a check on the results of Section 3. However, this measure of liquidity in the bond markets presents a few implementation challenges. We need to make some decisions on how we treat the data, which need to be made explicit. We use transactions reported on TRACE to compute the ILLIQ measure for every bond for every quarter, provided we observe at least five market lot trades (defined as a minimum of $\$ 1$ million of face value of the bond traded) in the bond in that quarter. This screen avoids using price observations from small trades that may not be reflective of the true return. The return on the bond is computed using the last traded clean prices of market lots on a given day only, and thus ignores the accrued coupon. In addition, transactions greater than $\$ 5$ million on TRACE are reported as $5 \mathrm{MM}+$, and transactions greater than $\$ 1$ million are occasionally reported as $1 \mathrm{MM}+$. We assume these to be $\$ 5$ million and $\$ 1$ million, respectively. The ratio of daily absolute returns to the daily trading volume is averaged over a quarter for every bond. Days on which there are no trades represent a zero return and a zero trading volume, and they are thus not included in the averaging. For the set of bonds for which we compute transaction cost, this gives us a quarterly measure of price impact of trading. Because there tend to be large positive outliers in the measure, we use the log of the measure in our regressions.

Univariate regressions of the log of ILLIQ on latent liquidity for each quarter are presented in Table 12. The coefficient of latent liquidity is consistently negative for all quarters. Overall, going from a percentile rank of 0 to $100 \%$ leads to a seven-fold reduction in the price impact.

We perform quarterly regressions of the ILLIQ measure on bond characteristics such as coupon, rating, issuer size, amount outstanding and age, average trade count during the quarter, and on the latent liquidity of the bond during the quarter. Table 14 presents these results. We find that the latent liquidity measure has explanatory power, over and above the other measures, including the realized trade volume. ${ }^{16}$ The coefficients have similar signs to those that we observe in the case of transaction costs. On average, going from the lowest latent liquidity to the highest latent liquidity bond (percentile rank 0 to 1 ), we find that other things remaining the same, the ILLIQ measure is almost halved.

\footnotetext{
15 The reader is encouraged to refer to Amihud (2002) for a detailed discussion of the measure.

${ }^{16}$ The performance of the regressions in the first seven quarters, from the third quarter of 2002 to the first quarter of 2004 , was poor in terms of both explanatory power as well as the statistical significance of the latent liquidity variable. This is probably due to the unrepresentative nature of the TRACE data in the initial period.
} 
Table 14

Price impact, liquidity and bond characteristics. This table shows, quarter by quarter, the relationship between Amihud's ILLIQ measure for a given quarter for a bond and two liquidity-related variables- the bond's percentile rank (from 0 to 1 ) based on latent liquidity for that quarter and the average number of trades in the bond during that quarter, along with five other bond characteristics - coupon, rating class (as a number from 1-7), Maturity (in years), amount outstanding of the bond in the market, and the size of the issuer as measured by total assets at the beginning of the year. The ILLIQ measure is computed quarterly using daily returns and trading volumes in each bond. The percentile rank is computed by ranking bonds every quarter in terms of latent liquidity and then dividing the bonds by the number of bonds available for that quarter. The first rank is given to the lowest liquidity security. This gives us a measure that is comparable from quarter to quarter. The sample consists of bonds that are traded on TRACE for a minimum of five days every quarter, and for whom information on latent liquidity is available from the State Street Corporation custody holdings database. The time period covered is July 2002 to June 2006. Robust t statistics are in parentheses.* significant at $5 \%$ level; ${ }^{* *}$ significant at $1 \%$ level

\begin{tabular}{|c|c|c|c|c|c|c|c|c|c|c|c|}
\hline & Latent Liquidity & Coupon & Maturity & $\log ($ Amount OS $)$ & $\log$ (Assets) & Age & Rating & Tradecount & Cons & Obs & $R^{2}$ \\
\hline Q302 & $\begin{array}{l}-1.179 \\
(1.26)\end{array}$ & $\begin{array}{l}0.027 \\
(0.30)\end{array}$ & $\begin{array}{c}0.090 \\
(5.15)^{* *}\end{array}$ & $\begin{array}{c}-1.448 \\
(4.68)^{* *}\end{array}$ & $\begin{array}{l}0.088 \\
(0.72)\end{array}$ & $\begin{array}{l}0.109 \\
(1.20)\end{array}$ & $\begin{array}{c}0.434 \\
(2.17)^{*}\end{array}$ & $\begin{array}{c}-0.001 \\
(3.90)^{* *}\end{array}$ & $\begin{array}{l}15.402 \\
(2.42)^{*}\end{array}$ & 176 & 0.45 \\
\hline Q402 & $\begin{array}{l}1.005 \\
(1.35)\end{array}$ & $\begin{array}{c}0.206 \\
(2.91)^{* *}\end{array}$ & $\begin{array}{c}0.057 \\
(4.51)^{* *}\end{array}$ & $\begin{array}{l}-0.646 \\
(2.47)^{*}\end{array}$ & $\begin{array}{l}0.026 \\
(0.30)\end{array}$ & $\begin{array}{c}0.173 \\
(2.64)^{* *}\end{array}$ & $\begin{array}{l}0.015 \\
(0.10)\end{array}$ & $\begin{array}{c}-0.001 \\
(3.36)^{* *}\end{array}$ & $\begin{array}{l}-1.669 \\
(0.30)\end{array}$ & 165 & 0.40 \\
\hline Q103 & $\begin{array}{c}-1.366 \\
(3.45)^{* *}\end{array}$ & $\begin{array}{l}0.097 \\
(1.65)\end{array}$ & $\begin{array}{c}0.055 \\
(7.97)^{* *}\end{array}$ & $\begin{array}{c}-1.135 \\
(10.22)^{* *}\end{array}$ & $\begin{array}{c}0.129 \\
(2.27)^{*}\end{array}$ & $\begin{array}{c}0.093 \\
(2.92)^{* *}\end{array}$ & $\begin{array}{l}0.061 \\
(0.52)\end{array}$ & $\begin{array}{c}-0.002 \\
(6.77)^{* *}\end{array}$ & $\begin{array}{c}9.286 \\
(4.24)^{* *}\end{array}$ & 527 & 0.52 \\
\hline Q203 & $\begin{array}{c}1.024 \\
(3.26)^{* *}\end{array}$ & $\begin{array}{c}0.200 \\
(3.99)^{* *}\end{array}$ & $\begin{array}{c}0.043 \\
(8.04)^{* *}\end{array}$ & $\begin{array}{c}-0.802 \\
(7.68)^{* *}\end{array}$ & $\begin{array}{l}-0.013 \\
(0.27)\end{array}$ & $\begin{array}{c}0.106 \\
(4.07)^{* *}\end{array}$ & $\begin{array}{l}-0.099 \\
(1.03)\end{array}$ & $\begin{array}{c}-0.004 \\
(9.34)^{* *}\end{array}$ & $\begin{array}{c}4.209 \\
(2.03)^{*}\end{array}$ & 598 & 0.59 \\
\hline Q303 & $\begin{array}{l}-0.650 \\
(2.12)^{*}\end{array}$ & $\begin{array}{c}0.105 \\
(2.31)^{*}\end{array}$ & $\begin{array}{c}0.048 \\
(9.43)^{* *}\end{array}$ & $\begin{array}{c}-1.042 \\
(11.30)^{* *}\end{array}$ & $\begin{array}{l}-0.007 \\
(0.16)\end{array}$ & $\begin{array}{c}0.100 \\
(4.23)^{* *}\end{array}$ & $\begin{array}{l}0.034 \\
(0.39)\end{array}$ & $\begin{array}{c}-0.002 \\
(8.38)^{* *}\end{array}$ & $\begin{array}{c}8.807 \\
(4.86)^{* *}\end{array}$ & 639 & 0.59 \\
\hline Q403 & $\begin{array}{l}-0.735 \\
(2.36)^{*}\end{array}$ & $\begin{array}{c}0.113 \\
(2.64)^{* *}\end{array}$ & $\begin{array}{c}0.057 \\
(11.28)^{* *}\end{array}$ & $\begin{array}{c}-0.818 \\
(9.59)^{* *}\end{array}$ & $\begin{array}{l}0.019 \\
(0.44)\end{array}$ & $\begin{array}{c}0.101 \\
(4.32)^{* *}\end{array}$ & $\begin{array}{l}-0.018 \\
(0.21)\end{array}$ & $\begin{array}{c}-0.001 \\
(4.90)^{* *}\end{array}$ & $\begin{array}{c}4.067 \\
(2.38)^{*}\end{array}$ & 681 & 0.50 \\
\hline Q104 & $\begin{array}{l}-0.469 \\
(1.35)\end{array}$ & $\begin{array}{l}0.092 \\
(1.95)\end{array}$ & $\begin{array}{c}0.059 \\
(10.70)^{* *}\end{array}$ & $\begin{array}{c}-1.019 \\
(10.77)^{* *}\end{array}$ & $\begin{array}{l}0.011 \\
(0.24)\end{array}$ & $\begin{array}{c}0.116 \\
(4.49)^{* *}\end{array}$ & $\begin{array}{l}0.127 \\
(1.44)\end{array}$ & $\begin{array}{c}-0.003 \\
(9.02)^{* *}\end{array}$ & $\begin{array}{c}7.597 \\
(4.09)^{* *}\end{array}$ & 668 & 0.60 \\
\hline Q204 & $\begin{array}{c}-1.047 \\
(2.83)^{* *}\end{array}$ & $\begin{array}{l}0.080 \\
(1.70)\end{array}$ & $\begin{array}{c}0.061 \\
(9.67)^{* *}\end{array}$ & $\begin{array}{c}-0.927 \\
(9.86)^{* *}\end{array}$ & $\begin{array}{r}-0.027 \\
(0.56)\end{array}$ & $\begin{array}{c}0.093 \\
(3.69)^{* *}\end{array}$ & $\begin{array}{l}0.048 \\
(0.51)\end{array}$ & $\begin{array}{c}-0.003 \\
(7.54)^{* *}\end{array}$ & $\begin{array}{c}6.784 \\
(3.70)^{* *}\end{array}$ & 729 & 0.51 \\
\hline Q304 & $\begin{array}{l}-0.617 \\
(1.50)\end{array}$ & $\begin{array}{l}0.076 \\
(1.40)\end{array}$ & $\begin{array}{c}0.065 \\
(9.51)^{* *}\end{array}$ & $\begin{array}{c}-0.860 \\
(8.06)^{* *}\end{array}$ & $\begin{array}{r}-0.026 \\
(0.48)\end{array}$ & $\begin{array}{c}0.097 \\
(3.35)^{* *}\end{array}$ & $\begin{array}{l}0.059 \\
(0.60)\end{array}$ & $\begin{array}{c}-0.002 \\
(4.45)^{* *}\end{array}$ & $\begin{array}{c}4.912 \\
(2.33)^{*}\end{array}$ & 782 & 0.36 \\
\hline Q404 & $\begin{array}{c}-0.715 \\
(2.71)^{* *}\end{array}$ & $\begin{array}{l}0.038 \\
(1.03)\end{array}$ & $\begin{array}{c}0.061 \\
(12.97)^{* *}\end{array}$ & $\begin{array}{c}-0.556 \\
(7.61)^{* *}\end{array}$ & $\begin{array}{l}0.031 \\
(0.74)\end{array}$ & $\begin{array}{c}0.116 \\
(6.53)^{* *}\end{array}$ & $\begin{array}{c}0.235 \\
(3.40)^{* *}\end{array}$ & $\begin{array}{c}-0.001 \\
(2.95)^{* *}\end{array}$ & $\begin{array}{l}-2.095 \\
(1.43)\end{array}$ & 1389 & 0.29 \\
\hline Q105 & $\begin{array}{l}0.026 \\
(0.10)\end{array}$ & $\begin{array}{l}0.058 \\
(1.64)\end{array}$ & $\begin{array}{c}0.063 \\
(13.45)^{* *}\end{array}$ & $\begin{array}{c}-0.770 \\
(10.47)^{* *}\end{array}$ & $\begin{array}{r}-0.038 \\
(0.98)\end{array}$ & $\begin{array}{c}0.129 \\
(7.70)^{* *}\end{array}$ & $\begin{array}{l}0.060 \\
(0.91)\end{array}$ & $\begin{array}{c}-0.001 \\
(5.54)^{* *}\end{array}$ & $\begin{array}{l}2.748 \\
(1.86)\end{array}$ & 1344 & 0.33 \\
\hline Q205 & $\begin{array}{r}-0.432 \\
(1.78)\end{array}$ & $\begin{array}{l}0.021 \\
(0.64)\end{array}$ & $\begin{array}{c}0.055 \\
(12.53)^{* *}\end{array}$ & $\begin{array}{c}-0.758 \\
(10.76)^{* *}\end{array}$ & $\begin{array}{l}0.010 \\
(0.29)\end{array}$ & $\begin{array}{c}0.084 \\
(5.99)^{* *}\end{array}$ & $\begin{array}{l}0.120 \\
(1.95)\end{array}$ & $\begin{array}{c}-0.001 \\
(4.26)^{* *}\end{array}$ & $\begin{array}{c}2.791 \\
(1.98)^{*}\end{array}$ & 1211 & 0.31 \\
\hline Q305 & $\begin{array}{c}-0.859 \\
(3.35)^{* *}\end{array}$ & $\begin{array}{l}0.024 \\
(0.74)\end{array}$ & $\begin{array}{c}0.061 \\
(13.32)^{* *}\end{array}$ & $\begin{array}{c}-0.645 \\
(8.88)^{* *}\end{array}$ & $\begin{array}{l}0.028 \\
(0.77)\end{array}$ & $\begin{array}{c}0.065 \\
(5.05)^{* *}\end{array}$ & $\begin{array}{c}0.146 \\
(2.32)^{*}\end{array}$ & $\begin{array}{c}-0.002 \\
(2.60)^{* *}\end{array}$ & $\begin{array}{l}0.464 \\
(0.32)\end{array}$ & 1182 & 0.31 \\
\hline Q405 & $\begin{array}{r}-0.470 \\
(1.67)\end{array}$ & $\begin{array}{l}0.047 \\
(1.35)\end{array}$ & $\begin{array}{c}0.060 \\
(12.87)^{* *}\end{array}$ & $\begin{array}{c}-0.616 \\
(7.76)^{* *}\end{array}$ & $\begin{array}{l}0.058 \\
(1.50)\end{array}$ & $\begin{array}{c}0.076 \\
(5.16)^{* *}\end{array}$ & $\begin{array}{l}0.111 \\
(1.65)\end{array}$ & $\begin{array}{c}-0.002 \\
(2.30)^{*}\end{array}$ & $\begin{array}{l}-0.636 \\
(0.41)\end{array}$ & 1142 & 0.29 \\
\hline Q106 & $\begin{array}{l}-0.652 \\
(2.02)^{*}\end{array}$ & $\begin{array}{c}-0.004 \\
(0.09)\end{array}$ & $\begin{array}{c}0.055 \\
(10.33)^{* *}\end{array}$ & $\begin{array}{c}-0.828 \\
(9.31)^{* *}\end{array}$ & $\begin{array}{l}0.017 \\
(0.39)\end{array}$ & $\begin{array}{c}0.076 \\
(4.39)^{* *}\end{array}$ & $\begin{array}{c}0.161 \\
(2.07)^{*}\end{array}$ & $\begin{array}{c}-0.002 \\
(4.18)^{* *}\end{array}$ & $\begin{array}{c}4.160 \\
(2.35)^{*}\end{array}$ & 931 & 0.33 \\
\hline Q206 & $\begin{array}{c}-0.901 \\
(3.02)^{* *}\end{array}$ & $\begin{array}{l}-0.012 \\
(0.32)\end{array}$ & $\begin{array}{c}0.052 \\
(11.47)^{* *}\end{array}$ & $\begin{array}{c}-0.357 \\
(5.42)^{* *}\end{array}$ & $\begin{array}{l}0.061 \\
(1.53)\end{array}$ & $\begin{array}{c}0.108 \\
(6.98)^{* *}\end{array}$ & $\begin{array}{c}0.210 \\
(3.17)^{* *}\end{array}$ & $\begin{array}{c}-0.004 \\
(7.84)^{* *}\end{array}$ & $\begin{array}{c}-5.568 \\
(4.10)^{* *}\end{array}$ & 1003 & 0.33 \\
\hline Overall & $\begin{array}{c}-0.720 \\
(9.01)^{* *}\end{array}$ & $\begin{array}{c}0.085 \\
(8.03)^{* *}\end{array}$ & $\begin{array}{c}0.058 \\
(41.98)^{* *}\end{array}$ & $\begin{array}{c}-0.825 \\
(38.46)^{* *}\end{array}$ & $\begin{array}{l}0.006 \\
(0.53)\end{array}$ & $\begin{array}{c}0.085 \\
(17.17)^{* *}\end{array}$ & $\begin{array}{c}0.061 \\
(3.15)^{* *}\end{array}$ & $\begin{array}{c}-0.001 \\
(20.55)^{* *}\end{array}$ & $\begin{array}{c}4.053 \\
(9.47)^{* *}\end{array}$ & 13167 & 0.38 \\
\hline
\end{tabular}

\section{Drivers of bond liquidity}

The preceding results give us confidence that latent liquidity captures an important aspect of liquidity. Next, we apply the measure to thinly traded bonds to discern which features of a bond lead to better liquidity. To investigate this question, we conduct a series of regressions in which the dependent variable is a particular metric of liquidity for a bond in the database at a particular time, while the independent variables are a set of the bond's characteristics. To perform these regressions, we compute the latent liquidity of each bond as of the beginning of a quarter. Because latent liquidity does not require transactions in the bond, we are able to conduct regressions in which latent liquidity is the dependent variable on all the bonds in our database. To better understand differences between traded and non-traded bonds, we also run these 
Table 15

Correlation between various liquidity measures:This table presents the correlation between the various measures of liquidity. The measures of liquidity are latent liquidity, trade days, trade count and traded market value. Each of the measures is expressed as a percentile. These variables are calculated from a set of dollar-denominated US corporate bonds, that traded at least once during a quarter, in the State Street Corporation custody trades database.

Latent liquidity Trade count Trade Days Traded Market value

\begin{tabular}{lllll}
\hline Latent liquidity & 1 & & & \\
Trade count & 0.1552 & 1 & & \\
Trade Days & 0.181 & 0.9031 & 1 & \\
Traded Market value & 0.1356 & 0.8233 & 0.7328 & 1
\end{tabular}

regressions separately on bonds that have traded at least once in a quarter and on bonds that have not traded at all.

In the analysis below, we use two trade-based liquidity measures for a bond. The first is trade count: the number of trades that occur in a particular quarter, as observed in the data. The second is trade volume: the average market value of trades for the bond each quarter. ${ }^{17}$ The purpose of using the more conventional measures of liquidity is to compare the empirical results we obtain for latent liquidity with those for more conventional measures. For trading volume and the trade count, we are, for obvious reasons, restricted to using only bonds that have traded at least once a quarter.

We first examine the correlations between our measure of latent liquidity and the two trade-based measures of liquidity, the results of which are presented in Table 15. Only bonds that traded at least once in a given quarter are included in this sample. The correlations between the two trade-based measures are fairly high, as is to be expected, because they all measure the frequency and size of trades. However, the correlations between latent liquidity and the trade-based measures are more modest. Given the relatively infrequent trading in even the most liquid US corporate bonds, apparently the trade-based measures do not measure the same latent effects that are captured in our measure. We next investigate the relation between the three measures and various characteristics of the bonds, in separate regressions. The results are presented in Tables 16.

Table 16 presents results from the regressions of these liquidity measures, on independent variables related to the characteristics of the bonds. These regressions have been performed on quarterly data from January 2000 to July 2006. In these regressions, we use latent liquidity, trade count and trading volume (in percentile ranks from 0 to 1 ) as the dependent variables, for both the traded and non traded sets of bonds. All columns present the coefficients and $z$-statistics of a random effects regression, where the observations for each bond are clustered to account for autocorrelations between the residuals for every bond. ${ }^{18}$

As one might expect, liquidity seems to be strongly correlated with the face amount of a bond outstanding or the issue size of a bond. The larger the issue size, the more liquid is the bond. A preview of this result was illustrated in Figure 2, where we saw that, when the size of the issue falls below $\$ 600$ million, the smaller an issue size, the less liquid is the issuance. However, Fig. 2 also showed that for amounts above $\$$ 600 million, issue size seems to have only a small effect on liquidity. For smaller issue sizes, liquidity clearly diminishes with size. Smaller sized issues do not appeal to a broad class of investors, since it would be difficult and costly to acquire a large position, which some institutional investors could require. Also, they may not qualify for inclusion in the popular bond indices. The link between issue size and liquidity has also been identified as important by other researchers such as Hong and Warga (2000), Alexander, Edwards, and Ferri (2000), and Hotchkiss, Warga, and Jostava (2002).

There are reasons to believe that the issue size might not be an adequate measure of size. For instance, bonds issued by larger issuers could be more liquid, irrespective of the issue size itself. To test for this, we

\footnotetext{
$\overline{17}$ We have also run these regressions using the number of days on which a bond trades as a measure of liquidity. However, there is a very high correlation between trade count and the number of days traded, and the results are very similar to those we observe for the trade count, and are not reported here.

${ }^{18}$ An alternate formulation using time-period dummies to account for any time variation in the relationships shows that they are insignificant and hence, is not reported.
} 
Table 16

Random effects regressions for the drivers of liquidity. This table shows the result of random effects regressions using three different measures of liquidity on the sample of dollar-denominated US corporate bonds consisting of the State Street custody database from January, 2000 to June, 2006. All variables are measured at a quarterly frequency. The liquidity variables used are the latent liquidity of the bond at the beginning of the quarter, the number of trades in a given bond in a quarter, and the quarterly volume of trading in terms of market value. The trading volume and trade count measures used here are based on information available from the database of State Street holdings, since there is no trading information available on TRACE prior to July, 2002. Ratings are based on the Moody's classification scheme represented as a cardinal scale: Aaa-1 Aa-2 A-3 Baa-4 and below Baa - 5. The liquidity variables are represented in terms of percentile values. To compute percentile values, we rank the bonds for each quarter in terms of the liquidity measures and divide by the number of bonds for which information is available for that measure for that particular quarter. Maturity dummies represent whether the bond had an original maturity of 5 years, 7 years, 10 years or 30 years. The remaining variables are self-explanatory. The regressions take the form of random effect regressions with the bond for which the liquidity is measured as the grouping variable. This is done so as to account for the fact that residuals for each bond might be correlated. We use clustered standard errors, where the clustering is done by bonds. Robust t statistics are in parentheses. ${ }^{*}$ significant at $5 \%$ level; ** significant at $1 \%$ level

\begin{tabular}{|c|c|c|c|c|c|}
\hline & \multicolumn{3}{|c|}{$\begin{array}{ll}\text { Latent Liquidity } \\
\end{array}$} & \multicolumn{2}{|c|}{ Trade Count Trade Volume } \\
\hline & $\begin{array}{c}(1) \\
\text { Traded }\end{array}$ & $\stackrel{(2)}{\text { Non-Traded }}$ & $\begin{array}{l}\text { (3) } \\
\text { All }\end{array}$ & $\begin{array}{c}(4) \\
\text { Traded }\end{array}$ & $\begin{array}{c}(5) \\
\text { Traded }\end{array}$ \\
\hline$\overline{\log \text { (Issue Size) }}$ & $\begin{array}{l}0.007 \\
(2.63)^{* *}\end{array}$ & $\begin{array}{l}0.009 \\
(4.24)^{* *}\end{array}$ & $\begin{array}{c}0.028 \\
(12.97)^{* *}\end{array}$ & $\begin{array}{c}0.114 \\
(29.27)^{* *}\end{array}$ & $\begin{array}{c}0.139 \\
(29.61)^{* *}\end{array}$ \\
\hline Log(Total assets) & 0.002 & 0.001 & -0.002 & $(12.97)^{* *}$ & $\begin{array}{l}0.011 \\
(8.09)^{* *}\end{array}$ \\
\hline Age (Years) & $(24.14)^{* *}$ & $\begin{array}{l}-0.007 \\
(9.65)^{* *}\end{array}$ & $\begin{array}{l}-0.013 \\
(21.23)^{* *}\end{array}$ & $(-0.021$ (25.78)** & $\begin{array}{l}-0.029 \\
(26.49)^{* *}\end{array}$ \\
\hline Rating & $\left(\begin{array}{ll}0.031 \\
(11.15)^{* *}\end{array}\right.$ & $\underset{(11.06)^{* *}}{0.035}$ & $\begin{array}{l}0.037 \\
(13.95)^{* *}\end{array}$ & $(13.81)^{* * *}$ & $\begin{array}{c}0.063 \\
(24.95)^{* *}\end{array}$ \\
\hline Coupon & $\begin{array}{l}0.003 \\
(2.40)^{*}\end{array}$ & $\begin{array}{c}-0.001 \\
(0.72)\end{array}$ & $\begin{array}{c}-0.000 \\
(0.42)\end{array}$ & $\begin{array}{l}0.002 \\
(i .92)\end{array}$ & $\begin{array}{l}0.011 \\
(8.06)^{* *}\end{array}$ \\
\hline Maturity (Years) & $\begin{array}{c}-0.000 \\
(0.69)\end{array}$ & $\begin{array}{c}-0.000 \\
(0.09)\end{array}$ & $\begin{array}{c}-0.000 \\
(0.17)\end{array}$ & $\begin{array}{l}0.000 \\
(0.84)\end{array}$ & $\begin{array}{l}0.001 \\
(2.51)^{*}\end{array}$ \\
\hline Maturity 5 (Dummy) & $\begin{array}{l}0.048 \\
(8.95) * *\end{array}$ & $\begin{array}{l}0.068 \\
(9.53)^{*} *\end{array}$ & $(11.44)^{* *}$ & $\begin{array}{l}-0.009 \\
(1.81)\end{array}$ & $\begin{array}{l}0.019 \\
(3.17)^{* *}\end{array}$ \\
\hline Maturity 7 (Dummy) & $\begin{array}{l}0.017 \\
(2.99)^{* *}\end{array}$ & $\begin{array}{l}0.041 \\
(4.80)^{* *}\end{array}$ & $\begin{array}{l}0.034 \\
(5.58)^{* *}\end{array}$ & $\begin{array}{l}-0.025 \\
(4.40)^{* * *}\end{array}$ & $\begin{array}{l}0.019 \\
(2.84)^{* *}\end{array}$ \\
\hline Maturity 10 (Dummy) & $\begin{array}{l}-0.0221 \\
(5.32)^{* *}\end{array}$ & $\begin{array}{l}-0.024 \\
(4.47)^{* * *}\end{array}$ & $\begin{array}{l}-0.021 \\
(5.31)^{* *}\end{array}$ & $\begin{array}{l}-0.018 \\
(4.74)^{* *}\end{array}$ & $\begin{array}{l}0.017 * * \\
(3.69)^{* *}\end{array}$ \\
\hline Maturity 30 (Dummy) & $\begin{array}{l}-0.047 \\
(5.82)^{* *}\end{array}$ & $\begin{array}{l}-0.042 . \\
(5.72)^{* *}\end{array}$ & $\begin{array}{l}-0.051 \\
(7.57)^{* *}\end{array}$ & $\begin{array}{l}-0.006 \\
(0.81)\end{array}$ & -0.025 \\
\hline Financial Sector (Dummy) & $\begin{array}{l}-0.006 \\
(1.17)\end{array}$ & 0.011 & $\begin{array}{l}0.002 \\
(0.46)\end{array}$ & $(10.059)^{* *}$ & $(12.83)^{* *}$ \\
\hline Industrial Sector (Dummy) & $\begin{array}{l}-0.011 \\
(2.55)^{*}\end{array}$ & $\begin{array}{l}-0.004 \\
(0.60)\end{array}$ & $\begin{array}{l}-0.006 \\
(1.44)\end{array}$ & $\frac{-0.025}{(5.69)^{* *}}$ & $\begin{array}{l}-0.035 \\
(6.43)^{* *}\end{array}$ \\
\hline Utilities (Dummy) & $\begin{array}{l}0.019 \\
(3.45)^{* *}\end{array}$ & (i.67) & 0.007 & $\begin{array}{l}-0.027 \\
(4.60)^{* *}\end{array}$ & $\begin{array}{l}-0.050 \\
(7.10)^{* *}\end{array}$ \\
\hline Private Placement (Dummy) & $\begin{array}{l}0.028 \\
(5.65)^{*} *\end{array}$ & $\begin{array}{l}-0.016 \\
(2.03)^{*}\end{array}$ & $\begin{array}{l}0.015 \\
(2.89)^{* *}\end{array}$ & $\begin{array}{l}0.014 \\
(2.59)^{* *}\end{array}$ & $\begin{array}{l}-0.011 \\
(1.77)\end{array}$ \\
\hline Convertible (Dummy) & $\begin{array}{l}0.024 \\
(2.42)^{*}\end{array}$ & $\begin{array}{l}0.076 .6 \% \\
(6.58)^{* *}\end{array}$ & $\begin{array}{l}-0.002 \\
(0.19)\end{array}$ & $(-0.165)^{*} *$ & $\begin{array}{l}-0.147 \\
(9.73)^{* *}\end{array}$ \\
\hline Callable (Dummy) & $\begin{array}{l}0.045 \\
(9.55)^{* *}\end{array}$ & $\begin{array}{l}0.019 \\
(3.15)^{* *}\end{array}$ & $\begin{array}{l}0.045 \\
(9.88)^{* *}\end{array}$ & $\begin{array}{l}0.029 \\
(5.61)^{* *}\end{array}$ & $\begin{array}{l}0.110 \\
(16.98)^{* *}\end{array}$ \\
\hline Putable (Dummy) & $\begin{array}{l}0.035 \\
(3.44)^{* *}\end{array}$ & $\begin{array}{l}0.061 * \\
(6.37)^{* *}\end{array}$ & $\begin{array}{l}0.0444^{*} \\
(5.04)^{* *}\end{array}$ & $\begin{array}{l}-0.038 \\
(3.88)^{* *}\end{array}$ & $\begin{array}{l}-0.064 \\
(4.82)^{* *}\end{array}$ \\
\hline Variable Interest (Dummy) & $\begin{array}{l}-0.023 \\
(2.49)^{*}\end{array}$ & 0.004 & $\begin{array}{l}-0.016 \\
(1.50)\end{array}$ & $\begin{array}{l}0.020 \\
(2.14)^{*}\end{array}$ & $\begin{array}{l}-0.015 \\
(1.22)\end{array}$ \\
\hline Floating Interest (Dummy) & $\begin{array}{l}-0.035 \\
(1.58)\end{array}$ & $\begin{array}{l}0.008 \\
(0.43)\end{array}$ & $\begin{array}{l}-0.011 \\
(0.63)\end{array}$ & $\begin{array}{l}0.045 \\
(2.08)^{*}\end{array}$ & $\frac{-0.107}{(3.98)^{* *}}$ \\
\hline Zero Coupon (Dummy) & $(3.17)^{* *}$ & 0.047 & $\begin{array}{l}0.089 \\
(3.78)^{* *}\end{array}$ & $\begin{array}{l}0.052 \\
(1.69)\end{array}$ & (i.056) \\
\hline Semiannual (Dummy) & $\begin{array}{l}0.050 \\
(2.25)^{*}\end{array}$ & $\begin{array}{l}0.088 \\
(4.77)^{* *}\end{array}$ & $\begin{array}{l}0.087 \\
(5.06)^{* *}\end{array}$ & $\begin{array}{r}-0.012 \\
(0.53)\end{array}$ & $\begin{array}{l}0.034 \\
(1.18)\end{array}$ \\
\hline Constant & $\begin{array}{l}0.356 \\
(6.63)^{* *}\end{array}$ & $\begin{array}{l}0.133 \\
(2.67)^{* *}\end{array}$ & $\begin{array}{l}-0.121 \\
(2.59)^{* *}\end{array}$ & $(-1.865 \%$ & $\begin{array}{l}-2.597 \\
(28.27)^{* *}\end{array}$ \\
\hline $\begin{array}{l}\text { Observations } \\
\text { Number of groups(Bonds) }\end{array}$ & $\begin{array}{l}85340 \\
11871\end{array}$ & $\begin{array}{l}90039 \\
11927\end{array}$ & $\begin{array}{c}175379 \\
15779\end{array}$ & $\begin{array}{l}85340 \\
11871\end{array}$ & $\begin{array}{l}85340 \\
11871\end{array}$ \\
\hline
\end{tabular}

include the total assets for each issuer at the beginning of the year, from Compustat. Although trading volume and trade counts are both higher for bonds issued by large issuers, there does not seem to be any indication that bonds by larger issuers are necessarily held by high-turnover funds (as measured by latent liquidity), once other bond specific characteristics have been controlled for.

The current age of the bond since issuance has a strong negative correlation with liquidity, i.e., a bond with a greater age (one that has been outstanding for a longer time) has less liquidity. This is the well known on-the-run versus off-the-run effect (see for instance Sarig and Warga (1989), Warga (1992), Chakravarty and Sarkar (1999), Hong and Warga (2000), Schultz (2001), and Hotchkiss, Warga, and Jostava (2002)). When a bond is initially issued, it is on-the-run and has much higher liquidity than some time later, after 
it has been outstanding for a while and becomes off-the-run.

The credit quality of a bond appears to be inversely correlated to liquidity, i.e., the higher the probability of default (and therefore the lower the credit rating), the higher the degree of liquidity. This is a surprising result, because most people tend to associate high credit quality with high liquidity. The simple explanation here is that bonds that have a high credit quality are usually held by long-term buy-and-hold investors such as insurance companies, which have long-term liabilities and hold fixed income assets for asset-liability matching reasons, because these bonds are less likely to default and force a portfolio re-balancing. In addition, some low-grade issues have a greater probability of rating migration, necessitating more frequent re-balancing.

There seems to be no clear relationship between the coupon rate on a bond and its liquidity as measured either by latent liquidity or by trade count. There does, however, seem to be evidence that higher coupon bonds have higher trading volume.

The current maturity of the bond seems to have a negligible effect on the liquidity of the bonds for all the measures. However, some effects are observed using the original maturity of the bonds at the time of issue. The original maturity variables are all dummy variables indicating the maturity of the bond when it was issued. From the coefficients here, it appears that bonds with lower original maturity, such as five and seven years, have greater latent liquidity than those with an original maturity of ten years or 30 years. Again, one explanation here is that long-term buy-and-hold investors such as insurance companies (which hold a substantial amount of the total bonds outstanding) have long-dated liabilities, against which they match long-dated assets. Once they find these assets, they tend to hold them.

We also see that if a bond's issuer is classified as being an industrial, financial or utility company, the bond tends to have a lower trading volume. However, when latent liquidity is used as a measure of liquidity, it is not clear which direction this effect has. Privately placed bonds tend to have lower liquidity in our sample when they are not traded, relative to public placements. However, the relationship reverses for traded privately placed debt. This issue needs to be examined more closely in future research.

Issuers generally have the choice of including various provisions into bond indentures. These provisions include option features that render the bond callable or putable, or they make the bond convertible into equity. In our results, callable bonds tend to have higher liquidity as measured by their latent liquidity, trading volume and trade count. The putability of a bond makes it more attractive to higher turnover funds, although they are not highly traded. These results are surprising because one might think that adding complexity such as optionality to a bond would make it more difficult to trade, because complexity could prevent less sophisticated investors from investing in these bonds, thus limiting the pool of potential investors. However, it could be that callable bonds are the standard security, since they form a greater proportion of the market and, hence are more liquid. The latter argument is consistent with the results for the convertibility feature of bonds, in the case of the trade-based measures, which show a negative relation between liquidity and the presence of the feature. In contrast, the latent liquidity regression results show no relationship between convertibility of a bond and its liquidity, perhaps because of the noise in the data, stemming from the small size of the sample.

Other characteristics of a bond such as whether the bond pays a fixed or floating coupon payment, or the periodicity of the coupon payments, do not seem to affect the liquidity of a bond in a conclusive manner. The zero-coupon nature of some bonds seems to make them more attractive to active funds. However, these are not highly traded, making it likely that they are primarily held for hedging purposes.

Some general comments about the various findings in this section are in order. First, the coefficients of the drivers of latent liquidity between traded and non-traded bonds are consistent both in magnitude and in direction, whenever they are statistically significant. Any differences that exist are in cases in which the coefficients are not statistically significant. The only exception is in the case for privately placed debt, which tends to have a higher latent liquidity if traded and a lower latent liquidity if not traded. This could be because traded privately placed debt has different characteristics from non-traded privately placed debt. On the whole, the results give us an indication that the latent liquidity measure can be extended to the illiquid segment of the US corporate bond market. Second, amount outstanding, age, rating class, and optionality seem to be the primary drivers of liquidity. Third, there are some important differences between the effect of certain bond characteristics, which are secondary drivers, on latent liquidity, trading volume, and trade count respectively. For instance, it is interesting that bonds with put options are held by high turnover 
investors, although they are not highly traded.

\section{Conclusion}

This paper presents a new measure of liquidity called latent liquidity and then applies this measure to a unique corporate bond database to analyze the characteristics of bonds that lead to higher liquidity. Unlike conventional measures of liquidity, such as trading volume and bid-ask spreads, latent liquidity does not use transaction information. Instead, it uses information about the ownership of securities to discern the accessibility of a security by a securities dealer. Therefore, latent liquidity has the important advantage of being able to provide a measure of liquidity in situations of low trading intensity, when transaction data are insufficient to compute traditional microstructure-based measures of liquidity, but liquidity is still an important issue.

We use latent liquidity to predict transaction costs in the liquid section of the corporate bond market. We show this by using data on all trades in bonds on a subset in our sample. We determine that latent liquidity has greater explanatory power than either transaction volume or bond specific characteristics on transaction costs in bonds, showing that it is not only the realized liquidity of the bond that matters for trading costs, but also the trading propensities of agents holding a bond, as measured by latent liquidity. Unconditionally, there is a 200 basis point difference between the lowest ranked and the highest ranked bonds (by percentile of latent liquidity), and holding other variables constant, there is around a 91 basis point difference.

Another manifestation of liquidity is in the form of the price impact of trading. We use the Amihud ILLIQ measure to compute the average quarterly price impact in bonds that trade actively on TRACE. We find that latent liquidity has explanatory power for price impact, both unconditionally and after controlling for other bond specific variables. Hence, latent liquidity has the potential to predict both transaction costs and price impact in the illiquid corporate bond market. We find that, unconditionally, an increase in the latent liquidity percentile from $0 \%$ to $100 \%$ leads to a seven-fold decrease in the price impact, while conditionally, it leads to around a two-fold decrease in the price impact.

In addition, we apply the latent liquidity measure to the relatively illiquid segment of the corporate bond market to determine the characteristics of corporate bonds that lead to higher or lower liquidity. We find that credit quality, the age of a bond, the size of a bond issue, and the industry sector are the primary drivers of liquidity. In addition, the original maturity value of a bond at issuance date, and provisions such as a call, put, and convertible options all have an impact on liquidity. If liquidity is priced (i.e., investors charge a liquidity risk premium), then the results of this paper indicate that the design of a bond can have a strong influence on the cost of the bond to the issuer, and the choice of which bond to hold (from the same issuer) can have a strong influence on the returns of an investor.

The directional relation between liquidity and bond characteristics is compared across the various liquidity measures. For the most part, the results for latent liquidity agree with traditional measures based on transaction data. We also determine that latent liquidity does not have a sample bias and can be used as a measure of liquidity uniformly across all the bonds in the corporate bond universe, whether traded or non-traded.

We believe that this research can also pave the way to explain some portion of the yield spreads on corporate bonds that cannot be explained by structural models of corporate credit risk. In future research, we will investigate this directly by incorporating our liquidity factors in structural models of credit risk. It would also be worth examining the significance of liquidity in determining asset returns. In particular, we propose to use this measure in explaining the cross-sectional variation in bond yield spreads, over their Treasury and swap rate benchmarks, after accounting for default risk. Based on the evidence presented in this paper, latent liquidity likely will explain at least part of the cross-sectional variation in bond yields, apart from the default premium. Our research will also address the issue of liquidity risk of corporate bonds and whether or not it is systematic in relation to the market-wide liquidity. An additional question that we will attempt to examine is whether liquidity risk is, in fact, priced and whether it is an important element of the total yield spread of the corporate bonds over comparable Treasury bonds. 


\section{Appendix A}

Chen, Lesmond and Wei (2006) use daily observations of bond returns to generate bond-level liquidity costs. They assume that the return generating process for bonds is driven by two factors: an interest rate factor and an equity market factor. We provide a brief exposition of their methodology. ${ }^{19}$

The true return generating process for any bond is then given by

$$
R_{j, t}^{*}=\beta_{j, 1} \text { Duration }_{j, t} \Delta R_{f, t}+\beta_{j, 2} \text { Duration }_{j, t} R_{t}^{S \& P}+\epsilon j, t
$$

where $R_{j, t}^{*}$ is the true unobserved return on the bond, $\Delta R_{f, t}$ is the change in the five-year risk-free interest rate and $R_{t}^{S \& P}$ is the daily return on the Standard $\$$ Poors' 500 index. Accounting for transaction costs, the realized return on the bond is given by

$$
\begin{array}{ll}
R_{j, t}=R_{j, t}^{*}-\alpha_{1, j} & \text { if } R_{j, t}^{*}<\alpha_{1, j} \text { and } \alpha_{1, j}<0 \\
R_{j, t}=0 & \text { if } \alpha_{1, j}<R_{j, t}^{*}<\alpha_{2, j} \\
R_{j, t}=R_{j, t}^{*}-\alpha_{2, j} & \text { if } R_{j, t}^{*}>\alpha_{2, j} \text { and } \alpha_{2, j}>0
\end{array}
$$

where $R_{j, t}$ is the observed return, $\alpha_{2, j}$ is the effective buy-side cost, and $\alpha_{1, j}$ is the effective sell-side cost. Assuming that daily bond returns are normally distributed gives a log likelihood function for the system, that can then be estimated.

$$
\begin{aligned}
L N L & =\sum_{1} \log \left(\frac{1}{\left(2 \pi \sigma_{j}^{2}\right)^{1 / 2}}\right) \\
& -\sum_{1} \frac{1}{2 \sigma_{j}^{2}}\left(R_{j}+\alpha_{1, j}-\beta_{j, 1} \text { Duration }_{j, t} \Delta R_{f, t}-\beta_{j, 2} \text { Duration }_{j, t} R_{t}^{S \& P}\right)^{2} \\
& +\sum_{2} \log \left(\frac{1}{\left(2 \pi \sigma_{j}^{2}\right)^{1 / 2}}\right) \\
& -\sum_{2} \frac{1}{2 \sigma_{j}^{2}}\left(R_{j}+\alpha_{2, j}-\beta_{j, 1} \text { Duration }_{j, t} \Delta R_{f, t}-\beta_{j, 2} \text { Duration }_{j, t} R_{t}^{S \& P}\right)^{2} \\
& +\sum_{0} \log \left[\Phi_{2, j}-\Phi_{1, j}\right]
\end{aligned}
$$

where $\sum_{1}$ represents the negative nonzero observed returns, $\sum_{2}$ represents the positive non-zero observed returns, $\sum_{0}$ represents zero observed returns, $\Phi_{1, j}$ is the normal probability density function evaluated for negative nonzero observed returns, and $\Phi_{2, j}$ is the normal probability density function evaluated for positive nonzero observed returns.

The round trip transaction cost (expressed as a percentage of bond price is then obtained as $\alpha_{2, j}-\alpha_{1, j}$. For the purpose of estimating transaction costs in our data set, we include all bonds for which we have observations in the TRACE database and for which latent liquidity and other bond characteristics are available from the SSC database. We match bonds on the basis of their Committee on Uniform Securities Identification Procedures (CUSIP) number. Returns are observed whenever a trade takes place in the bond, and they are zero otherwise. We reject bonds that have less than five trades (five measured returns) during a quarter in the TRACE database. We take the last traded price of a bond on a day as a measure of its end-of-day price. We use the constant maturity, five-year treasury yield to compute changes in the interest rate factor in equation 3 and contemporaneous return on the S\&P index as a measure of the equity market return. ${ }^{20}$ Quarterly measures of transaction costs so estimated are used in the regressions in Table 13.

\footnotetext{
${ }^{19}$ For a complete treatment of estimating transaction costs using limited dependent variable models, refer to Lesmond, Ogden and Trzcnka (1999) and Chen, Lesmond and Wei (2006).

${ }^{20}$ We also attempted an alternate specification using the interest rate and the changes in the credit default swap premium (obtained from a leading broker in the CDS market) for the issuer of a bond directly as a measure of the changes in its "true" return. However, the CDS market is liquid for only a fraction of all the bonds traded in the market, and often has fewer observed returns than the bond itself. Thus, doing so severely restricts the number of bonds for which we can estimate transaction costs.
} 


\section{References}

Alexander, G., Edwards, A., Ferri, M., 2000. The determinants of the trading volume of high yield corporate bonds. Journal of Financial Markets 3, 177-204.

Amihud, Y., 2002. Illiquidity and stock returns: cross-section and time series effects, Journal of Financial Markets 5, 31-56.

Amihud, Y., Mendelson, H., 1980. Dealership market: market making with inventory. Journal of Financial Economics 8, 31-53.

Amihud, Y., Mendelson,H., 1986. Asset pricing and the bid-ask spread. Journal of Financial Economics 17, 223-249.

Bessembinder, H., Maxwell, W., Venkataraman, K., 2005. Market transparency and institutional trading costs. Journal of Financial Economics, forthcoming.

Chacko, G., Stafford, E., 2004, On the costs of capital market transactions. Unpublished working paper, Harvard Business School, Cambridge, MA.

Chakravarty, S., Sarkar, A., 1999. Liquidity in US fixed income markets: a comparison of the bid-ask spread in corporate, government, and municipal bond markets. Staff Report Number 73, Federal Reserve Bank of New York.

Chen, L., Lesmond, D.A., Wei, J., 2006. Corporate yield spreads and bond liquidity. Journal of Finance, forthcoming.

Crabbe, L., Turner, C., 1995. Does the liquidity of a debt issue increase with its size? evidence from the corporate bond and medium-term note markets. Journal of Finance 50, 1719-1734.

Colin-Dufresne, P., Goldstein, R.S., Martin, J.S., 2001. The determinants of credit spread changes. Journal of Finance 56, 2177-2207.

De Jong, F., Driessen, J., 2005. Liquidity risk premia in corporate bond markets. Unpublished working paper, University of Amsterdam, Netherlands.

Duffie, D., Garleanu, N., Pedersen, L.H. 2005. Over the counter markets. Econometrica, 73, no. 6, pp. 1815-1847

Duffie, D., Garleanu, N., Pedersen, L.H. 2007. Valuation in over the counter markets. Review of Financial Studies, forthcoming.

Duffie, D., Singleton, K., 1997. Modeling term structures of defaultable bonds. Review of Financial Studies Special 12, 687-720.

Edwards, A., Harris,L., Piwowar, M., 2006, Corporate bond market transparency and transaction costs. Journal of Finance, forthcoming.

Elton, E.J., Gruber,M., Agrawal, D., Mann, C., 2001. Explaining the rate spread on corporate bonds. Journal of Finance 56, 247-277.

Eom, Y., Helwege, H.J., Huang, J.Z., 2004. Structural models of corporate bond pricing: an empirical investigation. Review of Financial Studies 17, 499-544.

Garman, M., 1976. Market microstructure. Journal of Financial Economics 3, 257-275.

Goldstein, M., Hotchkiss, E.H., Sirri, E.R, 2005. Transparency and liquidity, a controlled experiment on corporate bonds. Unpublished working paper, Boston College and Babson College, Boston, MA, and Wellesley, MA.

Hasbrouck, J., 2005. Trading costs and returns for US equities: Evidence from daily data, Unpublished working paper, New York University, New York, NY.

Ho, T., Stoll, H., 1981. Optimal dealer pricing under transactions and return uncertainty. Journal of Financial Economics 9, 47-73.

Hong, G., Warga, A., 2000. An empirical study of bond market transactions. Financial Analysts Journal $56,32-46$.

Hotchkiss, E., Ronen,T., 1999. The informational efficiency of the corporate bond market: An Intra-day Analysis, Unpublished working paper, Boston College and Rutgers University, Boston, MA, and New

Moreover, the magnitude of the transaction costs that we obtained are comparable to those obtained by Lesmond, Chen and Wei (2005), who use daily corporate bond quotes obtained from Datastream. 
Brunswick, NJ.

Hotchkiss, E., Warga,A., Jostova, G., 2002. Determinants of corporate bond trading: a comprehensive analysis. Unpublished working paper, Boston College.

Houweling, P., Mentink,A., Vorst, T., 2003. How to measure corporate bond liquidity. Unpublished working paper, Erasmus University Rotterdam, Netherlands.

Huang, J.Z.,Huang, M., 2003. How much of the corporate-treasury yield spread is due to credit risk?. Unpublished working paper, Pennsylvania State University, University Park, PA.

Kyle, A. S., 1985. Continuous auctions and insider trading. Econometrica 53, 1315-35.

Lesmond ,D.A., Ogden, J.P., Trizcnka, C.A., 1999. A new estimate of transaction costs. Review of Financial Studies 12, 1113-1141.

Liu, J., Longstaff, F. A., Mandell, R.E., 2004. The market price of credit risk: an empirical analysis of interest rate swap spreads. Journal of Business, forthcoming.

Longstaff, F., Mithal, S., Neis, E., 2005. Corporate yield spreads: default risk or liquidity? New evidence from the credit-default swap market. Journal of Finance, 60:5, 2213-2253.

Perraudin, W., Taylor A., 2003. Liquidity and bond market spreads. Unpublished working paper, Bank of England, London, UK.

Sarig, O., Warga, A., 1989. Bond price data and bond market liquidity. Journal of Financial and Quantitative Analysis 24, 367-378.

Schultz, P., 2001. Corporate bond trading costs: A peek behind the curtain. Journal of Finance 56, 677-698.

Stoll, H., 1978. The supply of dealer services in securities markets. Journal of Finance 33, 1133-1151.

Vayanos, D. 1998. Transaction costs and asset prices: A dynamic equilibrium model. Review of Financial Studies 11, 1-58.

Vayanos, D., Wang, T., 2005. Search and endogenous concentration of liquidity in asset markets, Journal of Economic Theory (forthcoming).

Warga, A., 1992. Bond returns, liquidity, and missing data. Journal of Financial and Quantitative Analysis $27,605-617$. 